\title{
PENGARUH DINAMIKA POLITIK INDONESIA TERHADAP EKSISTENSI HARIAN KOMPAS
} (1965-2012)

\author{
Andik Kurniawan \& Abraham Nurcahyo*
}

\begin{abstract}
Abstrak
Penelitian ini bertujuan untuk: 1) menemukan asal-usul dan peran tokoh pendiri Kompas; 2) mendapatkan gambaran sejarah cara bertahan Kompas dalam melewati Orde Baru; 3) mendapatkan pemahaman sejarah bagaimana strategi Kompas menempatkan diri di kultur politik era reformasi.

Penelitian dilaksanakan dengan metode historis. Digunakan jenis penulisan kajian pustaka untuk mendapatkan hasil fakta sejarah yang diinginkan, yakni: asal-muasal berdiri, tokoh pendiri, serta strategi dan taktik yang dilakukan Kompas dalam menjaga eksistensinya di dunia pers Indonesia dan di dalam konteks sejarah politik tanah air. Sumber data dalam penelitian ini berasal dari peraturan perundang-undangan, dokumen kerja lembaga, jurnal ilmiah, publikasi internet, dan buku-buku. Teknik yang digunakan dalam mendapatkan sumber adalah teknik studi pustaka. Diseleksi sejumlah dokumen primer dan publikasi-publikasi pendukung lainnya yang valid dan relevan dengan permasalahan guna mencapai tujuan penelitian. Teknik analisis data yang digunakan mengacu pada metodologi historis yang sistematikanya dimulai dari pertama, tahap heuristik, atau pencarian sumber. Kedua, kritik sumber, atau seleksi fakta. Ketiga, interpretasi, atau pemaknaan dari serangkaian bukti sejarah yang didapat. Keempat, penulisan hasil akhir dalam suatu bentuk narasi penjelasan sejarah.

Hasil penelitian membuktikan bahwa terdapat hubungan timbal-balik antara dinamika politik nasional dengan strategi umum yang menjadi kebijakan Dewan Redaksi Kompas. Kompas berhasil melalui tiga jaman ini dengan baik dan mengalami perkembangan skala usaha dengan luar biasa. Prinsip jurnalisme kepiting, suatu cara jurnalisme santun dan cenderung bermain aman, membantu Kompas berhasil melalui tiga jaman ini dengan baik, sekaligus mengalami perkembangan skala usaha dengan luar biasa.
\end{abstract}

\section{Kata kunci: Dinamika Politik, Harian Kompas}

\section{Pendahuluan}

Demokrasi merupakan salah satu cara dari manusia untuk menyelenggarakan suatu negara. Prinsip dasarnya adalah suatu negara yang yang menjadi milik bersama; dari rakyat, oleh rakyat, untuk rakyat. Istilah demokrasi berasal dari bahasa Yunani demos dan kratos. Demos artinya adalah rakyat, dan kratos artinya adalah kekuasaan. Dalam pengertian sehari-hari, demokrasi seringkali dimaknai sebagai government by the people (Miriam Budiardjo, 2009: 105).
Meskipun terdapat banyak ragam gaya demokrasi di dunia ini, dengan ciri khas masing-masing, namun terdapat kesepakatan tidak tertulis, bahwa pers atau media massa, merupakan wilayah demokrasi, democratic estate, keempat di samping eksekutif, yudikatif, dan legislatif. Sehingga negara-negara yang menghargai dan menggunakan prinsip demokrasi akan menempatkan pers sebagai suatu keharusan dalam kesehariannya. Atau dengan kata lain, bisa juga dikatakan bahwa karena begitu 
pentingnya kehadiran pers dalam mengawal keberlangsungan kehidupan demokrasi, adanya pers merupakan pilar demokrasi keempat di samping tiga pilar demokrasi lainnya (Amien Raies, 2008: 115).

Indonesia, sesuai tujuan negara yang tertuang dalam Pembukaan Undang-Undang Dasar 1945, termasuk negara yang memproklamirkan diri sebagai negara demokrasi. Para pendiri bangsa berkeyakinan bahwa sistem demokrasi yang diejawantahkan dalam suatu Negara Kesatuan Republik Indonesia adalah cara terbaik untuk menyatukan dan menjalankan suatu negara baru, yang tersusun atas unsur yang sangat majemuk ini.

Seperti diketahui bersama, istilah demokrasi sangat bertalian erat dengan istilah politik. Dengan meminjam istilah Miriam Budiardjo (2009: 14), bahwa politik dalam suatu negara adalah hal yang terkait mengenai masalah kekuasaan, pengambilan keputusan, kebijakan publik, dan alokasi atau distribusi, maka akan dapat didapatkan suatu relevansi yang kuat antara pers yang sehat dengan suasana politik dan iklim demokrasi yang bersahabat. Kondisi inilah yang bisa digunakan sebagai landasan kokoh guna melaksanakan pembangunan sesuai tujuan kemerdekaan.

Sejarah mencatat bahwa dalam perjalanannya sejak semula Indonesia dihadapkan akan dinamika berbangsa dan bernegara yang penuh tantangan. Setidaknya dengan menggunakan pendekatan sejarah politik, perjalanan Indonesia telah melalui tiga tahapan yakni, era orde lama, orde baru, dan era reformasi. Berangkat dari perspektif tersebut, keberadaan pers menarik untuk dikaji guna mendapatkan pemahaman seperti apa, kapan, dan dengan cara bagaimana pers menjalankan kegiatan jurnalistiknya dalam konteks hubungan saling pengaruhmempengaruhi dengan dinamika politik di tanah air.

Untuk mendapatkan suatu narasi rekontruksi yang lebih utuh bisa dimulai dengan menelusuri bagaimana mula-mula pers itu lahir. Kita juga bisa menengok lebih belakang lagi, dengan memikirkan mengapa orang mulai menulis lalu mereka mempublikasikan tulisannya.

Dimulai dari gambar di gua-gua, simbolsimbol catatan tangan sederhana di perlengkapan hidup manusia purba, berangsur manusia mulai menyadari betapa pentingnya suatu simbol dibakukan guna mengingat atau menyampaikan pesan tertentu. Simbol atau tanda-tanda khusus ini yang kelak kita kenal sebagai huruf.

Huruf membentuk kata, menyusun bunyi, merangkai kalimat. Kemudian sewaktu telah dikenal-digunakannya huruf inilah dikatakan manusia telah memasuki jaman sejarah. Jaman ketika manusia telah menggunakan tulisan dan berbagi pesan secara luas. Jaman yang tidak lagi sama dengan jaman sebelumnya, ketika masih berlangsungnya jaman sederhana yang 
belum mengenal dan menggunakan aksara. Pada masa sejarah ini manusia mulai mempublikasikan tulisan, termasuk sebagai sarana melestarikan cerita-cerita dongeng, bunga-bunga nasehat, maupun untuk meriwayatkan suatu pencapaian.

Tidak bisa dipungkiri, segera setelah diketemukannya mesin cetak oleh Guttenberg, sekitar tahun 1450, beraneka terbitan mulai bermunculan. Perubahan berkelanjutan dari tradisi lisan pada masamasa terdahulu berjalan beriring dengan suatu cara baru dalam berkomunikasi yaitu bahasa tulis, berikut seluruh media turunannya. Tulisan yang terpublikasi pada gilirannya merupakan suatu perkembangan mengenai cara manusia berkomunikasi dengan manusia lain baik yang sekelompok, lain kelompok, sejaman, dan generasi pada jaman berikutnya. Hal ini dibuktikan dengan dibuatnya prasasti-prasasti guna meriwayatkan pencapaian suatu tokoh ataupun suatu kaum tertentu.

Dari sekian produk tulis-menulis manusia, lahirlah satu bidang profesi yakni jurnalisme. Surat kabar adalah satu bentuk produk jurnalisme yang sangat populer di masyarakat. Surat kabar adalah suatu bentuk publikasi informasi secara berkala, biasanya harian, yang memegang peran penting dalam industri pers Indonesia sepanjang kelahirannya hingga sekarang.

Melacak jejak perkembangan pers di Indonesia tak lengkap untuk tidak mengapresiasi sebuah nama besar dalam industri ini yakni surat kabar harian Kompas. Tokoh besar yang paling berpengaruh dari grup Jawa Pos, selaku mitra bersaing di indutri yang sama, Dahlan Iskan (2011:1), mengakui bahwa Kompas merupakan koran terbesar. Satu yang paling berpengaruh. Berikut juga, Kompas Gramedia, induk perusahaan, yang sejatinya merupakan derivat dari kesuksesan surat kabar itu sendiri. Sebagaimana diketahui bahwa Kompas Gramedia merupakan suatu grup usaha yang mencakup unit usaha koran Kompas, kompas.com, toko buku Gramedia, penerbitan, percetakan, televisi, dan hotel.

Kompas adalah sebuah surat kabar yang terbit pertama kali pada tanggal 28 Juni 1965. Satu hari dalam panasnya suhu politik nasional. Didirikan oleh Petrus Kanisius Ojong, biasa dikenal dengan P.K. Ojong, dan Jakob Oetama. Kompas merupakan suatu surat kabar yang diterbitkan oleh golongan Katolik. Pada awalnya merupakan suatu usulan dari Ahmad Yani kepada koleganya di kabinet yakni Frans Seda agar kalangan Katolik mempunyai media massa sendiri. Ini adalah sebuah respon atas pengaruh komunis yang kian kuat di masyarakat dan di jajaran birokrat.

$$
\text { Kelahiran Kompas dilatari }
$$
berakhirnya politik demokrasi liberal yang ditandai dengan diumumkannya Dekrit Presiden. Sebuah pidato bersejarah yang menandai dimulainya tahapan demokrasi 
terpimpin. Sejak diumumkannya Dekrit Presiden, 5 Juli 1959, perkembangan politik mengarah pada pemusatan kekuatan ke tiga pihak utama. Pertama, Soekarno, Presiden dan pemimpin kharismatis yang mendirikan republik Indonesia. Kedua, Angkatan Bersenjata Republik Indonesia, ABRI, yang mendapat kekuatan dengan pemberlakuan status darurat perang di seluruh nusantara. Ketiga, pihak komunis yang memperluas pengaruhnya dengan cara meminjam kewibawaan Soekarno (Frans Seda dalam St. Sularto, 2011:107-108).

Pihak komunis dan militer melakukan usaha-usaha untuk memperkuat diri dengan serangkaian taktik propaganda. Usaha yang dilakukan pada gilirannya mencakup juga perang pola pikir melalui bidang jurnalistik. Frans Seda, di bulan April 1965 adalah seorang menteri perkebunan yang sekaligus adalah ketua dari Partai Katolik. Pihaknya mendapat himbauan dari Ahmad Yani untuk menyelenggarakan suatu surat kabar. Ahmad Yani, selaku Menteri/ Panglima Tentara Nasional Indonesia, TNI, Angkatan Darat, dengan mempertimbangkan koran-koran nonkomunis yang dibredel, menyarankan agar golongan Katolik mempunyai corong suaranya sendiri. Hal ini tentu tak lepas juga dari kepentingan politik Yani agar ada perimbangan terhadap pengaruh pihak komunis melalui media massa.

Setelah sebelumnya, pada tahun 1964, Partai Katolik pernah merencanakan menerbitkan sebuah surat kabar. Namanya Gagasan Baru atau Gagasan Pembaruan seperti yang diusulkan oleh Uskup Agung Semarang Mgr. Albertus Soegijapranata Sj. Wacana ini tidak dapat berkembang lebih lanjut karena tidak mendapat ijin dari Kodam Jaya yang dipengaruhi oleh pihak PKI. Maka ketika Frans Seda kemudian menyampaikan wacana penerbitan surat kabar ini kepada teman-temanya di kalangan pemimpin Partai Katolik pada awalnya beberapa di antara mereka pesimis akan adanya ijin dan masa depan untuk surat kabar baru ini nanti.

Sebagai tindak lanjut PK. Ojong dan Jakob Oetama menyepakati suatu penerbitan surat kabar yang mengusung tema humanisme dan toleran terhadap kemajemukan Indonesia. Kelompok Katolik yang ada di sekeliling dua pendiri Kompas akhirnya mendukung rencana penerbitan surat kabar yang dimaksud.

Mulanya Frans Seda dan temanteman menyiapkan nama Bentara Rakyat untuk surat kabar baru yang akan diterbitkan ini. Ketika usul penerbitan ini terdengar oleh Bung Karno, dalam salah satu kesempatan ketika dalam kapasitasnya sebagai anggota kabinet Presiden Soekarno, Frans Seda ditanya apakah berkenan diberikan nama untuk surat kabar itu. Bung Karno memberikan nama Kompas, yang artinya adalah pemberi arah dan jalan dalam mengarungi lautan dan hutan rimba demikian yang diceritakan Jakob Oetama, 
mengutip Frans Seda (dalam St. Sularto, 2011: 104-108).

Kompas menjalani tahun-tahun yang berat di awal berdirinya. Tidak kalah berat juga ketika giliran orde baru menggantikan era pemerintahan Soekarno. Kemudian ketika masa keemasan orde baru pupus seiring terbitnya fajar reformasi, kemampuan bertahan hidup Kompas semakin diuji dengan lanskap persaingan dunia usaha media yang terimbas juga wacana globalisasi dan digitalisasi media massa.

Pada awal-awal kelahirannya Kompas dihadapkan situasi politik nasional yang panas, kemudian era orde baru yang sarat dengan pengekangan kebebasan. Lantas dilanjutkan dengan era reformasi di mana di satu sisi kelonggaran mulai didapat, namun di sisi yang lain juga menjadikan industri media dimasuki pesaing dari luar negeri. Di era reformasi tercatat juga bersamaan dengan makin kompetitifnya industri media massa. Surat kabar Kompas tidak lagi hanya bersaing head to head dengan sesama surat kabar lainnya; era new media telah datang. Pesaing Kompas akhirnya juga adalah televisi, radio, dan juga situs-situs berita dalam jaringan internet.

Kompas sangat layak untuk dijadikan tokoh utama dalam dunia pers tanah air. Hipotesis kajian ini adalah bahwa Kompas dinilai berhasil untuk melaksanakan usaha penerbitan surat kabarnya. Parameter yang bisa digunakan guna menunjukkan keberhasilan Kompas antaranya adalah, kesinambungan terbitan selama 47 tahun, jumlah tiras pembaca, kekuatan finansial dan kemampuan memperluas lini usaha, serta pengaruh Kompas terhadap kehidupan masyarakat berbangsa bernegara.

Dalam perspektif Jakob Oetama (St. Sularto, 2011: 268) alur sejarah Kompas setidaknya telah berhasil melalui tiga jaman berbeda, yakni: 1) jaman pemerintahan Soekarno, 2) jaman pemerintahan Soeharto, dan 3) era reformasi. Melihat bahwa ada hubungan yang erat antara situasi politik dengan kelangsungan hidup pers. Mengingat akan segala segi terkait keberhasilan Kompas menempatkan diri di industri pers Indonesia, menarik untuk bisa melakukan suatu kajian mengenai bagaimana asal-usul Kompas lahir, siapa pendirinya, dan bagaimana sejarah perkembangannya mulai lahir tahun 1965 hingga 14 tahun umur era reformasi, tahun 2012.

\section{Tujuan Dan Manfaat Penelitian}

Berdasar pada rumusan masalah di atas, maka tujuan penelitian ditentukan sebagai berikut:

1. Untuk menemukan asal-usul dan peran tokoh pendiri Kompas

2. Untuk mendapatkan gambaran sejarah cara bertahan Kompas dalam melewati Orde Baru 
3. Untuk mendapatkan pemahaman sejarah bagaimana strategi Kompas menempatkan diri di kultur politik era reformasi

Adapun kegunaan penelitian yang dilaksanakan adalah sebagai berikut:

1. Bagi Program Pendidikan Sejarah Untuk mendapatkan tambahan bahan kajian bagi penelitian-penelitian berikutnya yang relevan dengan penelitian sejarah Kompas ini.

2. Bagi Pengembangan Ilmu Sejarah

Untuk mendapatkan analisa historis mengenai Kompas, lahir, dan sejarah tumbuhkembangnya sebagai pemimpin dalam industri pers Indonesia. Penelitian ini dimaksud juga untuk lebih mempopulerkan tema-tema penulisan sejarah kontemporer di Indonesia, khususnya untuk generasi muda.

3. Bagi Kompas

Untuk mendapatkan perspektif sejarah politik dan perspektif sejarah kontemporer dari perjalanan hidup mereka. Diharapkan, Kompas mendapatkan tambahan masukan dalam analisa pengambilan kebijakan di masamasa mendatang.

\section{Tinjauan Pustaka}

\section{A. Pers}

Menurut UU. No 40 Tahun 1999 tentang Pers.

Pers adalah lembaga sosial dan wahana komunikasi massa yang melaksanakan kegiatan jurnalistik meliputi mencari, memperoleh, memiliki, menyimpan, mengolah, dan menyampaikan informasi baik dalam bentuk suara, gambar, suara dan gambar, serta data dan grafik maupun dalam bentuk lainnya dengan menggunakan media cetak, media elektronik, dan segala jenis saluran yang tersedia.

Dalam Kamus Besar Bahasa Indonesia (2008:1), Pers adalah.

1) usaha percetakan dan penerbitan; 2) usaha pengumpulan dan penyiaran berita; 3) penyiaran berita melalui surat kabar, majalah, dan radio; 4) orang yang bergerak dalam penyiaran berita; 5) medium penyiaran berita, seperti surat kabar, majalah, radio, televisi, dan film.

Ana Nadhya Abrar (2011:7), berpendapat bahwa pers secara konseptual memiliki empat posisi yakni: a. media komunikasi; b. lembaga sosial; c. produk informasi; d. lembaga ekonomi. Hal ini mengandung pengertian bahwa wujud pers bisa dilihat setidaknya dalam empat konsep tadi. Jadi dapat disimpulkan bahwa pers adalah sebagai segala macam usaha percetakan, penerbitan, dan penyiaran suatu informasi.

\section{B. Surat kabar}

Istilah surat kabar dalam terminologi sehari-hari bersinonim dengan koran. Kamus Besar Bahasa Indonesia (2008:1), mendefinisikan koran sebagai lembaran-lembaran yang bertuliskan kabar, 
berita, atau semacam itu, terbagi dalam kolom-kolom dalam penyajiannya, dan terbit setiap hari atau rutin secara periodik.

$$
\text { Dalam definisi ensiklopedi }
$$

Britannica (2012:1), surat kabar adalah publikasi yang biasanya dikeluarkan secara berkala, bisa harian, mingguan, atau pada waktu reguler lain yang menyediakan berita, pandangan, fitur, dan informasi lain dari kepentingan umum dan yang sering menyertakan iklan dalam tiap terbitannya.

Microsoft Student 2009 (2008:1), mendefinisikan surat kabar sebagai suatu publikasi yang biasanya dikeluarkan setiap hari atau mingguan, fungsi utama yaitu untuk melaporkan berita. Banyak surat kabar juga memberikan informasi bagi pembaca, seperti laporan cuaca, jadwal televisi, dan daftar harga saham. Mereka memberikan komentar tentang politik, ekonomi, dan seni dan budaya, dan kadangkadang termasuk fitur hiburan, seperti komik dan teka-teki silang. Dalam hampir semua kasus dan dalam berbagai tingkatan level, surat kabar bergantung pada iklan komersial untuk pendapatan mereka. Jadi dapat disimpulkan bahwa yang disebut surat kabar atau koran adalah suatu lembaran berita yang terbit secara periodik, biasanya harian, dan umumnya didukung dengan pemuatan iklan.

\section{Kompas}

Kompas di sini merujuk pada pengertian sebuah surat kabar harian yang diterbitkan oleh kelompok media Kompas Gramedia. Kompas adalah surat kabar nasional yang memiliki pengaruh besar terhadap masyarakat. Dari hasil angket pembaca Kompas tahun 2008 diketahui bahwa profil pembaca utama Kompas adalah mereka yang termasuk golongan sosial ekonomi menengah ke atas. Hal ini bisa dilihat dari kondisi keuangan dan latar belakang pendidikan, setidaknya sebanyak $60 \%$ pembaca Kompas berpendidikan perguruan tinggi (Kompasiklan, 2008).

Kompas, sebuah surat kabar yang bersemboyan amanat hati nurani rakyat, merupakan sebuat surat kabar yang berfalsafahkan nilai perusahaan humanisme yang ber-Tuhan. Di mana dalam masa-masa sebelumnya, Kompas lebih dahulu dikenal mempopulerkan istilah humanisme transendental, namun sejak tahun 2000-an istilah humanisme yang ber-Tuhan lah yang dipakai.

\section{Kompas Gramedia}

Kompas Gramedia adalah sebuah kelompok usaha yang meliputi beberapa unit usaha yang memiliki kompetensi utama di bidang industri komunikasi massa, surat kabar, portal berita online, majalah, dan toko buku. Kompas Gramedia merupakan kelompok usaha yang membawahi surat kabar Kompas. Kompas Gramedia menyebut dirinya sebagai "suatu kelompok usaha yang awalnya berangkat dari sebuah cita-cita bahkan 'mimpi' sekelompok orang untuk 
mengembangkan ilmu pengetahuan .... Karena itu setelah Intisari, Kompas, dan disusul toko buku terpikir mendirikan percetakan sendiri." (St. Sularto, 2011: 103)

Kelompok usaha Kompas Gramedia merupakan suatu holding company, dengan berbagai macam perusahaan yang dikelolanya, yang awalnya dibangun untuk mendukung penerbitan Intisari tahun 1963, disusul mengawal surat kabar Kompas tahun 1965, kemudian pendirian toko buku Gramedia di tahun 1970.

Untuk itu, dalam penulisan kajian ini diperjelas bahwa istilah Kompas artinya mengacu pada surat kabar Kompas yang didirikan pada tahun 1965. Gramedia, atau toko buku Gramedia artinya adalah sebuah toko buku dengan segenap jaringannya di banyak kota besar di Indonesia; didirikan pertama kali pada tahun 1970 di Jakarta.

\section{Metode Penelitian}

Metode yang digunakan dalam penelitian menggunakan metode historis, di mana prosedur yang digunakan adalah sebagai berikut:

\section{Heuristik}

Heuristik adalah tahap di mana diselenggarakan pencarian fakta-fakta atau informasi yang sekiranya dianggap relevan dengan tujuan penelitian, selanjutnya disebut sebagai bukti sejarah. Latar belakang dan asumsi dasar yang telah disusun di awal digunakan sebagai titik tolak penelusuran bukti-bukti sejarah.

Ada dua studi pustaka yang digunakan untuk mendekati masalah yang diteliti, hal itu antara lain adalah:

a. Studi pustaka utama, dimaksud adalah studi sumber-sumber yang diterbitkan pihak Kompas sendiri yaitu sejumlah edisi surat kabar Kompas itu sendiri, buku biografi Pendiri Kompas Jakob Oetama, dan buku jurnalistik terbitan Kompas. Termasuk juga website resmi grup Kompas Gramedia: www.kompasgramedia.com,

www.kompas.com, dan www.kompasiklan.com. Keabsahan dan relevansi data yang didapatkan akan mendekati derajat kualitas dengan teknik wawancara mendalam, deep interview, terhadap petinggi Kompas ataupun Jakob Oetama sendiri.

b. Studi pustaka pendukung, dimaksud adalah mendapatkan sumber-sumber tambahan, selain terbitan pihak Kompas, dari buku, artikel jurnal ilmiah, bahanbahan ajar kuliah, atau makalah-makalah yang terkait dengan sejarah, publikasi, pendidikan, dan juga tentang Kompas.

\section{Kritik sumber}

Pada tahap ini bukti-bukti sejarah yang akan digunakan terlebih dahulu diseleksi. Suatu analisa kritis digunakan untuk mendapatkan suatu fakta atau bukti sejarah yang terbukti otentik dan relevan 
saja untuk dipakai menyelesaikan penelitian (Helius Sjamsudin, 2007:131)

a. Kritik Eksternal

Kritik Eksternal adalah suatu penelitian atas asal-usul dari sumber, suatu pemeriksaan atas catatan atau peninggalan berikut untuk mengetahui apakah sumber atau bukti atau kesaksian itu dirubah, dengan cara apapun, ataukah masih asli dari periwayat pertamanya (Helius Sjamsudin, 2007:134).

Kritik eksternal digunakan untuk setidaknya menjawab pertanyaanpertanyaan dasar sebagai berikut, Siapa yang mengatakan? Dirujuk langsung dari yang bersangkutan atau masih diubah melalui orang lain? Apakah sumber yang diperoleh memiliki kompetensi terkait dengan hal yang disampaikannya?

b. Kritik Internal

$$
\text { Helius Sjamsudin (2007:143) }
$$

mengutarakan bahwa tujuan dari pelaksanaan kritik internal adalah kepastian sahih tidaknya suatu sumber, atau bukti, atau kesaksian. Hal ini mengandung pengertian bahwa relevansi dari bukti sangatlah penting.

Tidak seperti kritik eksternal yang melihat suatu sumber dari sisi luar, kritik internal mencoba menyaring kesahihan suatu sumber melaui dua proses penting penyidikan: 1) Apa arti asli isi sumber dipahami dengan baik? 2) Kesaksian harus bisa dipastikan keasliannya. Apakah betulbetul asli isi kesaksiannya dan apakah si sumber layak meriwayatkan hal yang disampaikannya?

\section{Interpretasi}

Penggunaan logika untuk menghubungkaitkan fakta-fakta yang ada guna merekonstruksi tema sejarah yang diangkat atau diteliti. Bambang Purwanto (2001:112), memberikan suatu catatan penting dalam menuliskan atau membaca suatu tulisan sejarah,

....it is wrong to imagine that historian accurately portray the past. Historical description is historian concept of the past, or a subjective creation of the historian (....salah, jika membayangkan bahwa sejarawan dapat memotret masa lalu dengan (sangat) akurat. Deskripsi sejarah adalah (suatu) konsep mengenai (peristiwa) masa lalu, atau sebuah kreasi (pikiran) subyektif mengenai masa lalu oleh seorang sejarawan).

Subyektivitas penulis dalam menceritakan suatu narasi sejarah sebetulnya juga sudah diwelingkan kepada para penulis atau pembaca sejarah oleh Kuntowijoyo (2001:102105), namun beliau menyarankan sejauh mungkin supaya semangat menyusun suatu penulisan adalah obyektivitas. Guru Besar Sejarah Universitas Gadjah Mada (UGM) ini memandang setidaknya ada dua hal yang termaktub dalam komponen interpretasi, yakni: 1) analisis, 2) sintesis. Analisis berarti menguraikan, 
sedangkan sintesis artinya adalah menyatukan.

\section{Penulisan}

Pada tahap ini suatu tesis atau rumusan masalah yang ditentukan disusun menjadi suatu penjelasan sejarah, atau dengan kata lain tuturan sejarah. Berbeda dengan disiplin ilmu lain, sejarah seringkali mempunyai sifat seni dalam pelaksanaan metodologinya. Hal ini setidaknya disebabkan dua hal, pertama, si sejarawan tidak berada di tempat yang sama dengan kejadian. Kedua, si sejarawan tidak berada di waktu yang sama dengan kejadian. Waktu terjadinya peristiwa sejarah ada di masa lalu. Dua hal ini menyebabkan sang sejarawan harus cerdik menutur ulang, dengan keterampilan retorika tentu saja, seraya tidak boleh meninggalkan prinsip dasar keilmiahan suatu tulisan. Seringkali suatu tulisan sejarah berbentuk kisah, beberapa menyebutnya seperti dongeng fiksi, namun kekhasan penulisan sejarah adalah mengenai prinsip fokus dan bersifat kronologis tentang satu hal spesifik yang telah ditentukan di awal penelitian.

\section{Hasil Penelitian dan Pembahasan}

Hasil penelitian berupa kumpulan fakta-fakta sejarah terkait dinamika politik Indonesia dalam tiga jaman Indonesia merdeka, Orde Lama, Orde Baru, dan Orde Reformasi. Fakta-fakta sejarah yang didapat kemudian dinterpretasikan dan dinarasikan dalam tiga bagian, yakni: A. Kompas Di Era Orde Lama, B. Kompas Di Era Orde Baru, dan C. Kompas Di Era Orde Reformasi.

\section{A. Kompas Di Era Orde Lama}

\section{Era Orde Lama}

Orde lama adalah sebuah istilah yang umum digunakan untuk menyebut tata pemerintahan sebelum orde baru (KBBI, 2008:1). Orde Lama merupakan sebutan untuk suatu masa dalam kurun pemerintahan Sukarno. Ikrar Nusa Bhakti (2004:198), memandang sebutan Orde Lama adalah sebagai doktrin pemerintahan Suharto. Pemerintahan Suharto menyebut diri mereka Orde Baru agar menimbulkan suatu efek kontras terhadap pemerintahan demokrasi terpimpin, yang mereka katakan suatu sistem yang bangkrut dan busuk, di masa Sukarno.

Pada tanggal 5 Juli 1959, sebagai puncak krisis politik dalam negeri yang bersumber dari sistem parlementer yang liberal, Ir. Sukarno selaku kepala negara mengumumkan Dekrit Presiden yang menandai dimulainya masa demokrasi terpimpin. Terhitung sejak saat itu Indonesia tidak lagi menggunakan paham demokrasi liberal.

Dalam catatan Miriam Budiardjo (2009:129), era demorasi terpimpin berlangsung antara tahun 
1959-1965. Adapun ciri pokok dari masa demokrasi terpimpin adalah dominasi dari presiden, terbatasnya peranan partai politik, berkembangnya pengaruh komunis, dan meluasnya peranan Angkatan Bersenjata Republik Indonesia, ABRI, sebagai unsur sosialpolitik.

Dari satu segi, Dekrit Presiden 5 Juli memang merupakan satu terobosan untuk keluar dari kemacetan politik, melaui pembentukan kepemimpinan nasional yang kuat. Namun dalam prakteknya, pada era demokrasi terpimpin berlangsung beberapa penyimpangan konstitusi.

Penyimpangan yang dimaksud adalah, ketetapan MPRS No. III/1963 mengenai pengangkatan Ir. Sukarno sebagai presiden seumur hidup. Juga di mana sebelumnya presiden secara sepihak membubarkan Dewan Perwakilan Rakyat, hasil pemilu 1955, untuk diganti dengan suatu Dewan perwakilan Rakyat Gotong Royong tunjukkan presiden. Dewan Perwakilan Rakyat Gotong Royong ini lebih ditekankan peranannya sebagai pembantu pemerintah, sedangkan fungsi kontrol ditiadakan. Hal ini terlihat dengan diangkatnya pimpinan Dewan Perwakilan Rakyat Gotong Royong sebagai menteri. Di sini terlihat di mana praktek politik yang ada semakin jauh meninggalkan prinsip pemisahan kekuasaan model trias politica.

Dalam kaitan ini perlu dilihat Peraturan Presiden No. 14/1960, yang memberi kesempatan presiden untuk turut campur mengenai kewenangan legislatif, dalam hal anggota Dewan Pewakilan Rakyat tidak mencapai mufakat. Serta kewenangan campur tangan mengenai bidang yudikatif, melalui Undang-Undang No. 19/1964. Sukarno dalam otobiografi resminya (2011:340-341), menyatakan bahwa perihal pengangkatannya sebagai Presiden seumur hidup adalah atas suatu desakan situasi politik. Dengan adanya jaminan bahwa pihak kiri tidak akan mendominasi, serta pihak tentara Angkatan Darat tidak mendirikan suatu pemerintahan militer maka dipandang perlu memberi semacam garansi untuk kelompok-kelompok lain misalnya golongan Islam. Tetapi Bung Karno sendiri sebetulnya mengakui bahwa kondisi ini mungkin akan sangat menyulut tuduhan tidak demokratis, khususnya dari pihak-pihak luar negeri. Selain itu terjadi juga penyimpangan perundang-undangan di mana berbagai tindakan pemerintah dilaksanakan melaui Penetapan Presiden, Penpres, yang memakai dekrit presiden 5 Juli sebagai sumber hukum. Pemerintah juga melakukan kebijakan satu jalur rel revolusi, di 
mana partai politik dan pers yang dianggap menyimpang dari tujuan revolusi akan ditutup atau dibreidel. G 30 S/PKI telah mengakhiri era orde lama ini dan membuka jalan untuk dimulainya demokrasi pancasila. (Miriam Budiardjo, 2009:130).

\section{Para Pendiri Kompas}

Kompas didirikan oleh dua orang yakni P.K. Ojong dan Jakob Oetama. Merupakan tokoh terkemuka di bidang media massa yang sama-sama berlatarbelakang golongan Katolik.

\section{a. P.K. Ojong}

Petrus Kanisius Ojong, atau Auwjong Peng Koen, lebih dikenal dengan nama P.K. Ojong, merupakan satu dari dua orang yang disebut sebagai pendiri harian Kompas. Ojong adalah seorang keturunan keluarga perantauan dari Cina. Lahir di Bukittinggi, Sumatera Barat, pada tanggal 25 Juli 1920. Ojong dikenal sebagai seorang jurnalis yang berwatak terpuji. Pandangan hidupnya mewarnai nilai-nilai yang diusung oleh Kompas Gramedia, Hidup sederhana, berpikir mulia.

Ojong sebagai seorang tokoh jurnalistik adalah seorang yang piawai berbisnis dan terkenal memiliki kecerdasan intelejensia yang mumpuni. Terlahir dari sebuah keluarga pedagang tembakau yang berkecukupan di daerah payakumbuh, Ojong kecil terbiasa dididik untuk hidup irit dan bekerja keras. Masa belajarnya dijalani dengan menempuh pendidikan di Hollandsch Chineseesche School, HCS, Payakumbuh. Di sekolah dasar khusus warga keturunan Tionghoa ini Ojong mulai menampakkan dirinya sebagai seseorang yang berwatak serius dan berdisiplin diri yang tinggi. Sebelum merantau ke Jakarta Ojong menamatkan pendidikan dasar dan sekolah Mulo di Payakumbuh dan Padang. Kemudian Ojong melanjutkan pendidikannya di Sekolah Guru Atas Negeri di Jatinegara. Ojong pada akhirnya mendapatkan gelar S1 Sarjana Hukumnya di Universitas Indonesia pada tahun 1951.

Ojong pernah menjadi guru SD Budi Mulia di Mangga Besar Jakarta sebelum menjalani karir panjang di bidang pendidikan, kewartawanan, hukum, sosial, dan budaya. Beberapa di antaranya adalah wartawan Harian Keng Po dan Mingguan Star Weekly, Direktur Perusahaan Penerbitan PT Saka Widya, bendahara Pengurus Pusat Serikat Penerbit Surat Kabar, bendahara Yayasan Indonesia yang menerbitkan majalah kebudayaan Horison, bendahara Lingkaran Seni Jakarta, anggota Dewan Kurator lembaga Bantuan Hukum/ Lembaga Pembela Umum Jaya. Ojong juga tercatat pernah menjadi Ketua Dewan Pembina Yayasan Tarumanegara yang menyelenggarakan Universitas Tarumanegara. Dalam kalangan Katolik, Ojong pernah menjadi anggota Badan 
Pimpinan Pusat Partai Katolik, koordinator Serikat Pers Katolik Internasional wilayah Indonesia dan turut mendirikan serta menjadi direktur Kantor Berita Katolik Asia di Hongkong. Di bidang sosial, pernah mengetuai Yayasan Retino Blastoma di Jakarta tahun 1979 yang menyantuni para penderita cacat retina mata.

P.K. Ojong dan Jakob Oetama menerbitkan majalah Intisari pada tahun 1963. Kemudian pada tahun 1965 mendirikan harian Kompas, juga bersama Jakob Oetama. Pada gilirannya unit usaha yang mereka bangun berkembang pesat menjadi suatu kelompok usaha Kompas gramedia yang menempati posisi terhormat di kalangan bisnis nasional. P.K. Ojong meninggal pada tanggal 31 Mei 1980. Namanya diabadikan di halaman depan harian Kompas sebagai pendiri bersama-sama dengan mitra terbaiknya Jakob Oetama.

\section{b. Jakob Oetama}

Jakob Oetama lahir pada tanggal 27 September 1931 di Jogja. Pada awalnya bercita-cita sebagai pastor. Itu yang melatari pilihan studinya selepas Sekolah Menengah Pertama Pangudi Luhur, Yogyakarta, untuk memasuki pendidikan seminari, jenjang terendah dalam proses pendidikan calon imam Katolik pada tahun 1945.

Jakob Oetama, semula bernama Jakobus Oetama, mengikuti pendidikan seminari, berpindah-pindah dari satu tempat ke tempat yang lain. Setelah di Yogyakarta, beberapa bulan di Ambarawa, kemudian di Ganjuran, Bantul, kemudian di Muntilan, terakhir di Yogyakarta. Setelah lulus seminari menengah tahun 1952, pendidikan berlanjut di seminari tinggi di asrama yang sama. Namun baru tiga bulan mengenyam pendidikan, Jakob mengundurkan diri. Jakob Oetama tidak ingat apa alasan persisnya ia mengundurkan diri, bertahun-tahun ketika ia ditanyakan kembali perihal hal itu, tetapi yang pasti bersamaan dengan keluarnya dari seminari itu di dalam benak Jakob Oetama sekarang ialah ia ingin menjadi seorang guru.

Atas pertolongan salah satu kerabat ayahnya, Yosep Yohanes Soepatmo, yang aktif berkegiatan di Gereja Vincentius, Jakarta. Bertempat tinggal di dalam gang, tidak jauh dari gereja itu juga. Kebetulan juga Pak Patmo baru saja mendirikan Yayasan Pendidikan Budaya, yang mengelola sekolah-sekolah budaya. Pada bagian ini Jakob mengambil satu langkah bersejarah yang kelak mengubah hidupnya untuk selamanya dengan berpindah dari calon pastor menjadi calon guru, sekaligus dengan memilih tempat merantau ke Jakarta, pusat dari Indonesia. 
Jakob menjalani profesi sebagai guru SMP Mardiyuwana di Cipanas Jawa Barat tahun 1952-1953 dan pindah ke Sekolah Guru Bagian B, SGB, di Lenteng Agung, Jagakarsa, tahun 1953-1954, kemudian ke Sekolah Menengah Pertama, SMP, Van Lith di Jalan Gunung Sahari, tahun 1954-1956. Sekolahsekolah itu di bawah asuhan para pastor Katolik yang terhimpun dalam Kongregasi Ordo Fratrum Minorum, OFM, selain juga oleh tarekat Dominikan. Jakob kemudian mengajar sembari melakukan pekerjaan sebagai sekretaris redaksi majalah Penabur sejak tahun 1956.

Sambil mengajar SMP, Jakob mengikuti kuliah atau lebih tepatnya kursus B-1 Ilmu Sejarah, lulus. Kemudian kuliah di Perguruan Tinggi Publisitik hingga tahun 1961, letaknya di Jalan Menteng Raya di depan Sekolah Menengah Atasa, SMA, Kanisius, yang pada perkembangannya pindah Perguruan Tinggi Publisistik itu pindah lokasi di daerah Lenteng Agung, Jakarta Selatan, dan berganti nama menjadi Sekolah Tinggi Ilmu Sosial, STIS.

Diakui Jakob dengan belajar sejarah minatnya untuk menulis mulai tumbuh. Majalah Penabur, suatu mingguan berhaluan Katolik, diterbitkan dan diasuh oleh para pastor Fransiskan di mana Wahyu Sudibyo OFM sebagai pemimpin redaksi, dan pastor J.W.
Oudejans OFM sebagai pemimpin umum adalah tempat Jakob mengimplementasikan disiplin ilmunya. Oudejans merupakan seseorang yang diakui Ojong sangat berpengaruh dari balik layar. Meski tidak setiap waktu tampil di depan, tetapi banyak dari aktivitas majalah Penabur yang dinyalai oleh semangat dan bimbingannya. Jakob sendiri menjabat sebagai seorang sekretaris redaksi. Dalam menunaikan pekerjaannya, Jakob sekaligus mengisi majalah dengan menulis dalam banyak hal, banyak bidang. Jakob menulis biasanya dengan tanpa diberi identitas nama. Jakob menulis mulai dari hasil liputan lapangan sampai ulasan-ulasan sosial, politik, dan budaya.

"Saya sangat terbantu dan diperkaya oleh kepekaan humaniora yang terpupuk dan terkembang berkat pendidikan di seminari menengah," menurut Jakob seperti yang disampaikannya kepada St. Sularto (St. Sularto, 2011:36-40). Di mana dalam sekolah seminari memang dikenal memiliki kelebihan dalam mengajarkan masalah bahasa latin, filsafat, dan ilmuilmu kemanusiaan. Ilmu-ilmu kemanusiaan, filsafat, dan sastra klasik, ditambah dengan kegemaran membaca, didukung studi komprehensif masalahmasalah sosial budaya, sosial ekonomi, di kemudian hari memang sangat 
membantu Jakob dalam mengembangkan diri di bidang jurnalistik.

$$
\text { Jakob sendiri mempunyai }
$$
pandangan mengenai pentingnya filsafat logika dan filsafat antropologi dikuasai oleh jurnalis. Logika, menurut Jakob, melatih berpikir secara jernih, berurutan, logis, melihat hakikat persoalan dalam konteks yang masuk akal-bernalar. Filasafat antropologi membantu jurnalis untuk mengenal pikiran-pikiran besar dalam sejarah dan masa terkini manusia (St. Sularto, 2011:40).

Lulus B-1 Sejarah dengan nilai rata-rata 9, Jakob sebetulnya direkomendasi untuk mendapat beasiswa di University of Colombia, Amerika Serikat, oleh salah satu guru sejarahnya, Sejarah Eropa, seorang pastor Belanda, Jesuit, Van den Berg Sj. Jakob mengalami fase galau, di mana pada saat itu sebenarnya keinginan untuk melanjutkan profesi sebagai guru sudah mulai goyah, yang lama-kelamaan semakin condong ke arah keinginan menjadi seorang jurnalis. Jakob mengalami masa-masa gamang untuk memilih lanjutan karir antara wartawan profesional atau seorang guru profesional. Hingga akhirnya untuk mengatasi kegamangan itu Jakob melamar sebagai dosen di Universitas Parahyangan, Unpar, Bandung. Diterima, bahkan sudah disiapkan rumah dinas. Unpar juga merekomendasi bahwa beberapa tahun setelah dia mengajar akan ditugaskan untuk menyelesaikan Ph.D di Universitas Leuven, Belgia. Hingga pada satu waktu Pastor J.W. Oudejans OFM menanyakan kepada Jakob mengenai ketetapan hati Jakob yang sesungguhnya. Jakob mengaku mendapat semacam anjuran untuk fokus memilih satu bidang antara seorang guru/ dosen dengan jurnalis. Jika guru sudah banyak tapi wartawan belum, begitu pertimbangan yang disampaikan Oudejans. Sehingga, dari titik itulah Jakob akhirnya betul-betul merasa didorong untuk fokus kepada salah satu pilihan bidang hidup yang akan ditekuninya (St. Sularto, 2011:43).

Jakob kemudian melanjutkan studi untuk menempuh kuliah Komunikasi Massa di Fakultas Sosial Politik di Universitas Gadjah Mada. Lulus pada tahun 1961, Jakob sudah dekat dengan PK Ojong yang mengenalkannya dengan pers dan konsekuensi politik, di mana Ojong baru saja mengalami pembredelan Keng Po dari pemerintah Orde lama. Ojong sendiri masih aktif di Star Weekly, yang pada awal tahun 1961 sudah menunjukkan gejala akan mengalami nasib serupa dengan Keng Po. PK Ojong dan Jakob Oetama akhirnya sepakat untuk mendirikan media baru bernama Intisari yang pertama kali dibicarakan pada tahun 1961 dan terbit perdana dua tahun kemudian. Satu mini 
magazine yang mengambil bentuk dari majalah internasional Reader Digest, suatu media yang berisikan tentang sari pati perkembangan ilmu-ilmu pengetahuan dan teknologi dunia. Ada kesamaan antara Ojong dan Jakob yang membantu mereka bisa menyatu. Ojong menyukai sejarah, terutama juga pada bidang militer. Jakob Oetama memiliki ijasah B-1 Sejarah, lulus tahun 1956. Keduanya guru, keduanya wartawan, dan keduanya Katolik.

Bersama P.K. Ojong, pada bulan Agustus 1963 Jakob akhirnya bisa menerbitkan Intisari dan menjadi Pemimpin Redaksi sampai tahun 1999. Selain itu, semenjak Harian Kompas diterbitkan pertama kali tanggal 28 Juni 1965, jabatan Pemimpin Redaksi juga dipegang olehnya.

Tahun 1980, setelah meninggalnya P.K. Ojong, Jakob merangkap jabatan Pemimpin Umum Kompas. Seiring dengan semakin berkembangnya bisnis yang dirintisnya, Jakob ditetapkan sebagai Presiden Direktur Kompas Gramedia. Pada gilirannya, reorganisasi perusahaan di tahun 2008 menetapkannya selaku Presiden Komisaris Kompas Gramedia. Jakob juga pernah diangkat menjadi dosen tidak tetap Jurusan Komunikasi Fakultas Ilmu Sosial dan Politik Universitas Indonesia. Pada tanggal 17 April 2003, Universitas Gadjah Mada menganugerahkan gelar Doctor Honoris Causa kepada Jakob Oetama atas dasar pertimbangan kepeloporan berikut kepemimpinannya dalam dunia media massa Indonesia.

Jakob Oetama dikenal dengan konsep humanisme transendental. Sebuah prinsip humanisme yang berlandaskan keimanan, yang dalam perwujudannya harus selalu disegarkan dalam menghadapi segala perubahan serba cepat dalam masyarakat yang diusungnya, ini sekaligus sebagai visimisi harian Kompas dalam menentukan langkah kebijakan pemberitaan.

Selain kedua nama tersebut seorang tokoh lain yang dianggap berjasa dalam melemparkan gagasan pendirian suatu koran kepada PK Ojong dan Jakob Oetama adalah Frans Seda. Frans Seda, dengan nama lengkap Fransiscus Xaverius Seda, adalah seorang tokoh terkemuka dari golongan intelektual Katolik. Pernah menjabat Menteri di penghujung Orde Lama dan awal-awal dimulainya Orde Baru.

Frans Seda juga tercatat sebagai ketua Partai Katolik pada kurun waktu 1961-1968. Atas bantuannya persyaratan ijin terbit 3.000 tanda tangan pelanggan Kompas bisa dipenuhi. Cara yang ditempuh adalah dengan memobilisasi golongan Katolik di Flores untuk membantu memberikan bukti langganan mereka. Frans Seda memang 
seorang putra daerah kelahiran Flores. Seda lahir pada tanggal 4 Oktober 1926 dan pada tanggal 31 Desember 2009, meninggal di Jakarta.

\section{Asal-usul Nama Kompas}

Kompas adalah sebuah surat kabar yang terbit pertama kali pada tanggal 28 Juni 1965. Satu hari dalam panasnya suhu politik nasional. Didirikan oleh Petrus Kanisius Ojong, biasa dikenal dengan P.K. Ojong, dan Jakob Oetama. Kompas merupakan suatu surat kabar yang diterbitkan oleh golongan Katolik. Pada awalnya merupakan suatu usulan dari Ahmad Yani kepada koleganya di kabinet yakni Frans Seda agar kalangan Katolik mempunyai media massa tersendiri. Ini adalah sebuah respon atas pengaruh komunis yang kian kuat di masyarakat dan di jajaran birokrat.

$$
\text { Kelahiran Kompas dilatari }
$$
berakhirnya politik demokrasi liberal yang ditandai dengan diumumkannya Dekrit Presiden. Sebuah pidato bersejarah yang menandai dimulainya tahapan demokrasi terpimpin. Sejak diumumkannya Dekrit Presiden, 5 Juli 1959, perkembangan politik mengarah pada pemusatan kekuatan ke tiga pihak utama. Pertama, Soekarno, Presiden dan pemimpin kharismatis yang mendirikan republik Indonesia. Kedua, Angkatan Bersenjata yang mendapat kekuatan dengan pemberlakuan status darurat perang di seluruh nusantara. Ketiga, pihak komunis yang memperluas pengaruhnya dengan cara meminjam kewibawaan Soekarno (Frans Seda dalam St. Sularto, 2011:107-108).

Pihak komunis dan militer melakukan usaha-usaha untuk memperkuat diri dengan serangkaian taktik propaganda. Usaha yang dilakukan pada gilirannya mencakup juga perang pola pikir melalui bidang jurnalistik. Frans Seda, di bulan April 1965 adalah seorang menteri perkebunan yang sekaligus adalah ketua dari Partai Katolik. Pihaknya mendapat himbauan dari Ahmad Yani untuk menyelenggarakan suatu surat kabar. Ahmad Yani, selaku Menteri/ Panglima TNI Angkatan Darat, dengan mempertimbangkan koran-koran nonkomunis yang dibredel, menyarankan agar golongan Katolik mempunyai corong suaranya sendiri. Hal ini tentu tak lepas juga dari kepentingan politik Yani agar ada perimbangan terhadap pengaruh pihak komunis melalui media massa.

Setelah sebelumnya, pada tahun 1964, Partai Katolik pernah merencanakan menerbitkan sebuah surat kabar. Namanya Gagasan Baru atau Gagasan Pembaruan seperti yang diusulkan oleh Uskup Agung Semarang Mgr. Albertus Soegijapranata Sj. Wacana ini tidak dapat berkembang lebih lanjut karena tidak mendapat ijin dari Kodam 
Jaya yang dipengaruhi oleh pihak PKI. Maka ketika Frans Seda kemudian menyampaikan wacana penerbitan surat kabar ini kepada teman-temannya di kalangan pemimpin Partai Katolik pada awalnya beberapa di antara mereka pesimis akan adanya ijin dan masa depan untuk surat kabar baru ini nanti.

Sebagai tindak lanjut PK. Ojong dan Jakob Oetama mengajukan pandangan perihal suatu penerbitan surat kabar, namun bukan sebagai surat kabar partai, tetapi sebagai surat kabar milik masyarakat umum, suatu surat kabar nasional. Suatu surat kabar yang mengusung tema humanisme yang bersendi pada multikulturnya Indonesia. Partai Katolik yang ada di sekeliling dua pendiri Kompas akhirnya menyetujui konsep penerbitan surat kabar yang dimaksud (St. Sularto, 2011:112).

Mulanya Frans Seda dan temanteman menyiapkan nama Bentara Rakyat untuk surat kabar baru yang akan diterbitkan ini. Ketika usul penerbitan ini terdengar oleh Bung Karno, dalam salah satu kesempatan dalam kapasitasnya sebagai anggota kabinet Presiden Soekarno, Frans Seda ditanya apakah berkenan diberikan nama untuk surat kabar itu. Bung Karno memberikan nama Kompas, yang artinya adalah pemberi arah dan jalan dalam mengarungi lautan dan hutan rimba demikian yang diceritakan Jakob Oetama, mengutip
Frans Seda (dalam St. Sularto, 2011:104108).

\section{Menjawab Panggilan Jaman}

Kompas pertama kali terbit pada tanggal 28 Juni 1965 dengan format cetak empat halaman, dan dibuat sebanyak 4.800 eksemplar. Pada waktu itu untuk mendapatkan surat ijin terbit dari penguasa sangatlah sulit. Aparatur yang menguasai perijinan dikuasai oleh kelompok komunis. Terdapat pula suatu syarat yang mempersulit penerbit yakni telah terdapat sekurang-kurangnya 3.000 orang pelanggan media massa yang bersangkutan (Kompas Iklan, 2010:1).

Apabila pada masa liberal kebebasan berpolitik sedemikian longgarnya, maka setelah 5 Juli 1959, Ir. Sukarno atas dalih kepentingan nasional menempuh sejumlah langkah politik yang tidak populer. Di antaranya pembatasan partai politik dan pengekangan kebebasan pers.

Namun sejak meletusnya peristiwa dini hari 1 Oktober 1965, atau yang umum dikenal dengan nama Gerakan 30 September PKI, G 30S/ PKI, suhu politik nasional mencapai temperatur tertinggi sepanjang sejarah Indonesia merdeka. Di satu sisi bisa dikatakan bahwa yang terjadi adalah saling berhadapannya pihak komunis dan pihak Angkatan Darat, beserta pendukung masing-masing. Namun di 
sisi yang lain, boleh juga dikatakan bahwa sejarah tahun 1965 ini merupakan momentum yang berhasil dimanfaatkan pihak Angkatan Darat untuk melaksanakan suatu operasi militer besar-besaran untuk memusnahkan komunis berikut musuhmusuh politik Angkatan Darat yang lain. Suatu konflik yang tentu saja akhirnya dimenangkan Angkatan Darat, yang tidak hanya memusnahkan PKI namun lebih jauh lagi mampu melakukan suksesi kepemimpinan tertinggi atas tokoh nasional terbesar sepanjang sejarah Indonesia, Ir. Sukarno.

Praktis semenjak Oktober 1965, sudah tidak sama lagi posisi politik Bung Karno dengan masa-masa sebelumnya. Bisa dikatakan tahun 1965 adalah titik balik prestasi politik Bung Karno. Satu demi satu kekuasannya dipreteli, dimulai dari dualisme kepemimpinan secara de facto. Mengapa terjadi dualisme? Karena meskipun Sukarno adalah Presidennya, tetapi secara realita Jenderal Suharto adalah pelaksana pemerintahannya. Dengan modal dukungan militer dari korps-nya dan sejumlah, dugaan, dukungan dari Amerika Serikat dan negara-negara Barat, bedil dan uang Suharto mampu melucuti secara bertahap kekuasaan Sang Pemimpin Besar Revolusi (Roosa, 2006, terjemahan Institut Sejarah Sosial Indonesia, 2008:250-252). Hingga pada akhirnya pada tanggal 27 Maret 1968 secara sah MPRS yang sebagian besar merupakan pendukung gerakan pengusung Orde Baru, dengan ketuanya Nasution mengangkat Suharto sebagai Presiden Republik Indonesia. Menurut Suharto dalam buku otobiografi resminya (1996:228), tokoh tua yang telah lelah itu kemudian memberikan surat tanda selamat dan menyatakan tidak berminat lagi terhadap kedudukan tertinggi yang akhirnya diraih Jenderal Suharto.

Harus diingat, segera setelah peristiwa 1 Oktober 1965 pihak tentara praktis sudah menguasai kecamuk yang terjadi di Jakarta. Garis komando dan dukungan kemampuan organisasi dalam masa genting, plus kepemilikan senjata membantu mereka menguasai secara de facto kendali Ibu Kota. Dengan diumumkannya status darurat, maka diambil langkah-langkah strategis untuk mengkondisikan suasana. Salah satu langkah yang diambil adalah dibredelnya sejumlah media massa yang dianggap pro pihak komunis. Sejumlah media antaranya, Warta Bhakti, Bintang Timur, dan Suluh Indonesia ditutup oleh pihak tentara. Kompas sendiri mengalami era ini dari seumur bayi kelahiran mereka yang turut diminta menghentikan penerbitan. Pada waktu itu hanya harian Angkatan Bersenjata, milik ABRI dan Berita Yudha, milik ABRI Angkatan Darat yang diijinkan terbit (St. Sularto, 
2011:10). Namun ternyata permintaan tidak terbit ini hanya berlangsung selama tiga hari saja, pada tanggal 6 Oktober 1965, Kompas kembali menyapa pembaca dengan korannya, yang nota bene dianggap tidak membahayakan stabilitas yang dibangun pihak Angkatan Bersenjata. Sedangkan bagi seorang sejarawan Universitas Wisconsin, Amerika, selama kurun waktu 19651966, di mana tidak jauh beda dari media massa nasional lainnya, Kompas justru adalah sekutu, atau sekurang-kurangnya adalah golongan independen di luar polarisasi komunis versus Angkatan Darat yang kenyataannya membantu menggalakkan propaganda histeria anti komunis (Roosa, 2006, terjemahan Institut Sejarah Sosial Indonesia, 2008:30).

Masa Orde Lama mencerminkan adanya kegelisahan warga masyarakat dalam mewujudkan dirinya sebagai satu bangsa, dengan beraneka warna komponen penyusunnya. Ketika euforia kemerdekaan selepas dari Belanda begitu menggebu-gebu dirasakan sejumlah pemimpin publik. Di waktu yang sama sesungguhnya tantangan baru yang tidak kalah beratnya datang, yakni menjaga persatuan nasional sebagai suatu negara baru yang multikultur, sekaligus suatu negara baru yang mempunyai agenda pembangunan yang begitu padat dan mendesak untuk segera dilaksanakan.

Harian Kompas, secara tegas menyatakan diri bukan sebagai koran kelompok Katolik saja, melainkan sebagai suatu koran nasional yang menghormati keberagaman masyarakat (St. Sularto, 2011:112). Berangkat dari hal itulah Kompas menjalankan usaha penerbitan korannya, sekaligus meneguhkan diri untuk dapat menyumbang peran sebagai penjaga harmoni keberagaman anak bangsa.

\section{B. Kompas Di Era Orde Baru}

\section{Orde Baru}

$$
\text { Orde Baru adalah sebuah }
$$
sebutan untuk menandai era kekuasaan Suharto. Masa ini berlangsung mulai 11 Maret 1966-20 Mei 1998 (Kamus Besar Bahasa Indonesia, 2008:1).

Era ini dimulai dengan diterimanya Surat Perintah Sebelas Maret 1966 oleh Suharto dari Presiden Sukarno. Meski awalnya Sukarno bersikukuh bahwa surat ini bukan berarti penyerahan kekuasaan negara, namun pada prakteknya Suharto memanfaatkan Surat Perintah 11 Maret ini sebagai legitimasi kekuasaan untuk melakukan suksesi terhadap pemerintahan Sukarno.

Slogan dari Orde Baru adalah melaksanakan Pancasila dan Undang- 
Undang Dasar 1945 secara murni dan konsekuen; suatu kontras untuk dibandingkan dengan masa demokrasi terpimpin, yang dituding banyak melakukan pengesampingan konstitusi. Dalam melaksanakan rangka mencapai tujuan itu dilakukan serangkaian perombakan kebijakan politik, baik dalam urusan dalam negeri maupun menyangkut hubungan luar negeri Indonesia.

Metode yang digunakan Orde Baru dalam membangun kekuasaan adalah militerisasi aparatur pemerintahan. Menempatkan perwira-perwira militer pada struktur birokrasi, khususnya dari kelompok Angkatan Darat. Serta memanfaatkan kerjasama sistem ekonomi dan permodalan dari kelompok Barat. Berbeda sekali dengan pemerintahan Sukarno yang cenderung berseberangan dengan negara-negara Barat, yang disebutnya negara-negara neo kolonialis-imperialis, neokolim.

\section{Corak Politik Pemerintahan Orde}

\section{Baru}

Orde Baru adalah suatu era pemerintahan bergaya kendali militer yang terpusat di tangan Presiden Suharto. Pada era orde baru Angkatan Bersenjata Republik Indonesia terdiri atas empat unsur yakni, angkatan darat, angkatan laut, angkatan udara, dan angkatan kepolisian. Dengan dalih dwi fungsi ABRI, Jenderal Suharto mengkonstruksi tata kelola pemerintahan negara Indonesia untuk dilaksanakan secara terkendali oleh para prajurit militer bersenjata.

Unsur militer, khususnya TNI Angkatan Darat, masuk ke jajaran birokrasi mulai dari kabinet, parlemen, hingga ke level desa. Sebagai anak emas Presiden, pihak angkatan darat juga diberi keleluasaan untuk menempatkan pasukan dari level markas besar, Mabes, Jakarta, tingkat propinsi, tingkat wilayah eks karisidenan, tingkat kota/ kabupaten, tingkat kecamatan, hingga tingkat desa. Ini dibuktikan dengan diselenggarakan komando teritori mulai Mabes TNI AD, Markas Komando Daerah Militer, Makodam, Markas Komando Resimen Militer, Komando Distrik Militer ,Kodim, Komando Rayon Militer, Koramil, dan hingga pos bintara pembina desa, Babinsa. Kebijakan yang sama tidak diterapkan terhadap angkatan laut, dan udara.

Sedangkan angkatan kepolisian memang memiliki jenjang pasukan yang hampir setara dengan TNI AD di tiap tempat, namun peranannya dikaburkan oleh 
dominasi angkatan darat. Ini bisa dilihat di mana untuk tingkat pusat ada markas besar, kemudian di tingkat propinsi ada markas kepolisian daerah, Mapolda, di tingkat wilayah eks karisidenan ada markas kepolisian wilayah, Mapolwil, di tingkat kabupaten/ kota ada markas kepolisian resort, Mapolres, dan di tingkat kecamatan ada markas kepolisian sektor, Mapolsek., namun acapkali terjadi fungsi pengamanan dan ketertiban di lapangan, yang seharusnya adalah wilayah kerja kepolisian, didahului oleh militer. Misalnya, ketika ada pencuri tertangkap di masyarakat, umumnya oleh masyarakat lebih diinginkan untuk diproses di Koramil. Sementara pihak Koramil sendiri sering latah juga untuk berinisiatif mengambil alih fungsifungsi kerja dari pihak kepolisian.

Meskipun terkadang pemimpin-pemimpin tentara dari unsur Angkatan Udara, atau Angkatan Laut memegang posisi strategis di lembaga TNI, namun hal ini baru dimulai di era reformasi, semasa Presiden Abdurrahman Wahid, dilanjutkan penerusnya yakni Megawati Sukarnoputri. Hal mana yang merupakan suatu balasan Angkatan Darat terhadap kesetiaan Angkatan Udara terhadap kepemimpinan Sukarno di era Orde Lama dan kedekatan pihak angkatan udara dengan pihak komunisme pada waktu itu juga. (Kingsbury, 2005:8)

Sebagaimana umumnya suatu pemerintahan bercorak junta militer, kebebasan berpendapat dan berekspresi di masa ini sangat dibatasi. Negara dijalankan untuk melayani rakyat, namun sekaligus secara permanen juga untuk selalu mencurigai dan berwaspada kepada rakyat seperti halnya terhadap musuh perang.

Pemerintahan orde baru mempopulerkan doktrin trilogi pembangunan dalam program pembangunannya: 1) Pertumbuhan ekonomi yang tinggi, 2) Pemerataan pembangunan dan hasil-hasilnya, 3) Stabilitas nasional yang mantap dan dinamis. Dalam poin mewujudkan stabilitas nasional yang mantap inilah, prakteknya menjadi suatu dalih dari negara untuk secara berkala dan sistematis harus bertindak keras terhadap rakyatnya. Elson menggambarkan dengan akurat abstrak dari orde baru dengan istilah peniadaan pluralisme, korporatisme Pancasila, serta kecurigaan yang permanen terhadap rakyatnya sendiri. Presiden Soeharto adalah negara, mirip 
dengan gaya raja/ sultan yang totaliter. Sehingga ketika Soeharto turun jabatan kekacauan yang ada di masyarakat seolah-olah menimbulkan anggapan betapa sulitnya mengurus Indonesia (Elson, 2001, terjemahan S. Wahono \& IGH Bagoesoka 2005:594).

Kekuasaan yang efektif dari Presiden selaku pemimpin tertinggi eksekutif negara berbanding terbalik dengan kekuasaan legistlatif DPR/ MPR yang lemah. Pada era orde baru kekuasaan negara terpusat pada diri Presiden, Militer Angkatan Darat, serta Golongan Karya.

\section{Orde Baru Versus Komunis}
Pemerintah Orde Baru menjadikan Partai Komunis Indonesia, PKI, komunisme beserta segenap pendukungnya sebagai musuh negara. Diselenggarakan langkah-langkah pembasmian kelompok komunis secara sistematis dan cepat. Biasanya dengan menggunakan organ militer sebagai mesin utama eksekusi, lantas dengan lihai menerapkan taktik nabok nyilih tangan, melibatkan rakyat atau kelompok agama untuk membantu menghabisi target-target yang dianggap musuh (Roosa, 2006, terjemahan Institut Sejarah Sosial Indonesia, 2008:35-36).

Mengapa

gerakan penumpasan PKI itu laku keras? Setidaknya didapat tiga alasan, pertama frustasi masyarakat akan situasi di era Orde Lama, kedua stigma anti Tuhan yang dilekatkan pada PKI dan konco-konconya mudah menyulut kemarahan kelompok masyarakat, utamanya dari kalangan agamawan atau simpatisan kelompok agama. Ketiga, adalah karena PKI sendiri memiliki ciri perilaku yang provokatif dan berhaluan radikal dalam melakukan aktivitas politiknya, sehingga mudah menimbulkan gesekan dengan masyarakat, dan rupanya ini bagi sebagian menjadi dendam.

$$
\text { Sebagai suatu gerakan }
$$
penumpasan yang bertitel gerakan balasan untuk G $30 \mathrm{~S} /$ PKI pada hakekatnya operasi militer ini meluas dan berlarut-larut. Dasar argumen yang digunakan sebagai pembenarannya adalah PKI menyimpan potensi bahaya laten. PKI sewaktu-waktu melakukan pengkhianatan, pemberontakan dengan tujuannya adalah mengganti Pancasila dan UUD 1945 dengan sistem komunis. Bahkan ketika situasi sudah mulai tenang, katakanlah di tahun 1990-an, gaya intimidasi, tudingan "kamu PKI", dan kadang-kadang penculikan untuk 
musuh politik masih saja dilakukan. Sedikit ada yang dianggap berani dengan pemerintah segera dialamatkanlah cap PKI kepadanya. Cap PKI ini sangat menjadi momok dan trauma di masyarakat. Terlanjur diterima sebagai stereotipe bahwa PKI adalah setan atau binatang culas yang keji. Sekali seseorang dicap PKI, maka tamat sudah kebahagiaan hidupnya.

Mereka yang tersangkut tuduhan komunis tidak punya banyak pilihan atau keleluasaan membela diri. "Berani dengan Orde Baru? Awas diciduk!" sudah menjadi pendidikan sehari-hari dalam keluarga Indonesia selama kurun waktu 1966-1998 . Diproses sendiri oleh aparat militer atau dipakakne, bahasa jawa: diumpankan, samasama merupakan suatu hukuman yang menakutkan. Tentara dan organ pendukung utama Orde Baru sangat terbiasa, tepatnya disetel otomatis untuk latah memberikan stempel PKI bagi yang tidak disukainya. Ironisnya, bahaya laten komunis atau bahaya PKI baru yang bisa muncul sewaktu-waktu rupanya lebih terasa sebagai doktrin saja dari penguasa. Sebab di sisi yang lain, para perajurit militer atau para preman pendukung Orde Baru sendiri kebanyakan tidak sampai tahu secara ilmiah-akademis tentang apa sebenarnya itu komunis. Pemerintah Orde Baru terlanjur untuk mengembangkan suatu budaya pemerintahan teror, atau dalam kata lain adalah Republik Patuh. Pemerintah mengkondisikan masyarakat untuk memiliki kepatuhan yang suci, meski untuk mencapai itu dilakukan serangkaian teror, yang kerap sampai penghilangan nyawa seseorang. Banyak dari kelompok pengamat, misalnya sejarawan Asvi Warman Adam, yang curiga bahwa pada akhirnya tidak hanya kubu komunisme saja yang dibasmi, akan tetapi kubu Sukarnois dan musuhmusuh politik yang lain juga turut dilenyapkan (Mahkamah Konstitusi Republik Indonesia, 2006:30-32).

\section{Pokok-pokok Kebijakan Pers Orde} Baru

Pelaksanaan sensor yang ketat pada pers merupakan citra yang melekat kuat dalam kebijakan pers pemerintahan Orde Baru. Pengawasan yang ketat inilah yang menjadikan terjadinya kasus pemberedelan atau pelarangan terhadap sejumlah surat kabar dan majalah.

\section{Sejarah} mencatat, pembredelan pers pertama kali di awal Orde Baru adalah lanjutan dari 
peristiwa Oktober 1965. Pada awal Orde Baru semua media massa yang diduga berkaitan dengan PKI diberangus. Media yang diijinkan hidup hanya media massa yang mendukung kekuasaan rezim Orde Baru, yang sebagian besar didukung secara langsung maupun tidak langsung oleh pihak Angkatan Darat, seperti Berita Yudha, Jakarta, dan Pikiran Rakyat, Bandung, termasuk sejumlah terbitan mahasiswa yang pro Orde Baru, seperti Mahasiswa Indonesia, Bandung, dan Harian Kami, Jakarta. Ironisnya, di sisi lain rezim ini menghidupkan kembali media massa yang diberangus di era Sukarno, seperti Abadi, Indonesia Raya, Nusantara, dan Pedoman.

Penindasan terhadap pers dimulai ketika pemerintah mengajukan Penanggung Jawab Redaksi harian Nusantara ke Pengadilan karena membeberkan korupsi dan dianggap menghina Pemerintah Republik Indonesia dan Presiden Suharto (M. Fadjroel Rachman dalam Sukri Abdurrachman, 2003:390-391). Adapun peraturan perundang-undangan pers yang berlaku pada masa orde baru antara lain: Undang-Undang No. 11/1966 tentang ketentuan pokok pers; Undang-Undang No. 4/1967 tentang perubahan Undang-Undang No. 11/ 1966; dan Undang-Undang No. 21/1982 tentang perubahan atas Undang-Undang No. 11/1966 (Sukri Abdurrachman, 2003: 403).

Dilihat dari sudut perundang-undangan itu, di era Orde Baru payung hukum UU Pokok Pers berstatus mandatory right, tidak untuk melindungi pers merdeka. Di era Orde Baru, payung hukum yang digunakan untuk mengendalikan pers adalah sejumlah Peraturan Pemerintah, PP, dan Peraturan Menteri, Permen. Di mana secara resmi penyelenggaraan pers dipayungi oleh UU Pokok Pers No. 11/1966 junto No. 4/1967 junto No. 21/1982. UU tersebut memberi kewenangan kepada Menteri Penerangan untuk, lewat PP dan Permen, menjadi penentu kebijakan penyelenggaraan pers. PP dan Permen tersebut menjadi alat kendali Menpen untuk mengatur, mengawasi dan memberi sanksi termasuk membredel pers. Nasib kemerdekaan pers tergantung dari goodwill politik pemerintah. PP dan Permen itu tidak ada bedanya dengan mandor dengan pentungan. Terserah Menpen, sesuai petunjuk Bapak Presiden, apa yang mau dilakukan dengan kewenangannya itu. Bermunculan sejumlah PP 
antara lain tentang: 1) pembatasan jumlah penerbitan pers, 2) pembatasan jumlah iklan dan halaman, 3) organisasi pers yang hanya membolehkan satu asosiasi wartawan dan satu asosiasi penerbitan pers. Karena kemerdekaan pers dapat disebut sebagai mandatory right bersumber dari kebijakan pemerintah lewat PP dan Permen, maka mandat yang sudah diterima pers dapat dicabut. Lewat UU Pokok Pers No. 11/1966, pers mendapat mandat bahwa tidak ada pembredelan pers. Tetapi pada 1984, sejalan dengan makin otoriternya pemerintah, Menpen mencabut mandat itu. Lewat Permen No. 1 Menpen boleh membatalkan izin penerbitan pers. Apa yang terjadi kemudian? Pers yang masih berani memberitakan hal-hal yang tidak sesuai petunjuk terancam dibredel dan atau dipidana penjara (Leo Batubara, 2009:570-571).

\section{Jurnalisme Kepiting Kompas}

Pada mulanya istilah jurnalisme kepiting yang dialamatkan kepada Kompas merupakan olok-olok dari Rosihan Anwar (St. Sularto, 2011:144). Maksudnya, kepribadian Kompas bergerak ala kepiting, mencoba melangkah setapak demi setapak untuk mengetes seberapa jauh kekuasaan memberikan toleransi kebebasan pers yang ada. Jika aman, kaki kepiting bisa maju beberapa langkah, jika kondisi tak memungkinkan, kaki kepiting pun bisa mundur beberapa langkah.

Rosihan Anwar adalah seorang tokoh pers nasional. Pemimpin Redaksi Pedoman yang ditutup pemerintah pada tanggal 15 April 1974. Sebagai sejawat sekaligus sahabat, Rosihan menilai bahwa gaya koran Jakob cenderung main aman. Di satu sisi dimaknai sebagai kurang tajam dan kurang menggigit, sangat tidak sama dengan gaya berani Mochtar Lubis, namun di sisi yang lain pilihan ini adalah pilihan cerdas untuk bisa survive selama kepemimpinan rezim militer di tanah air.

Jakob Oetama sebenarnya tidak menyukai istilah Jurnalisme Kepiting itu, tetapi lebih lanjut lagi istilah itu terlanjur menjadi identitas Kompas. Identitas itu akan terus berlaku dan bahkan perlu terus dikembangkan. Menurut Jakob, istilah itu lebih menunjukkan cara bagaimana pers harus fleksibel di suatu negara yang tahapan kedewasaan demokrasinya belum bagus (St. Sularto, 2011:152).

Bagi segenap kalangan yang belum pernah merasakan secara langsung pemerintahan di era Suharto mungkin agak kesulitan membayangkan bagaimana seorang figur yang senantiasa tersenyum manis 
dalam publikasi-publikasi gambar dirinya itu dinilai sebgai sosok yang dingin dan angker. Jakob Oetama (dalam St. Sularto, 2011:21-22) mencatat bahwa setidaknya Presiden Suharto dua kali melakukan peringatan secara lisan kepada Kompas dalam suatu kesempatan tatap muka secara langsung. Pertama, pada peringatan Hari Pers Ke-32 tanggal 9 Februari 1978 di Solo, Jawa Tengah. Dalam kesempatan berjabat tangan dengan Jakob, Suharto sambil tersenyum mengancam dengan singkat, "Aja meneh-meneh!"

Peristiwa kedua yang digunakan Suharto adalah pada saat di atas pesawat dalam penerbangan lawatan kenegaraan dari Yugoslavia dan Uni Soviet pulang ke tanah air pada tahun 1980-an. Berbeda dengan cara mengatakan ancaman di Solo, di atas pesawat itu Suharto dalam kaitan menjawab pertanyaan wartawan perihal liputan-liputan koran menyangkut gerakan mahasiswa tahun 1980-an yang mirip-mirip masa tahun 1970-an mengatakan dengan bersuara lantang dan tertawa terbahak-bahak, "tak gebuk!" Diikuti sikap tangan mengepal dan siap melayangkan tinju. Dibesarkan dalam kultur Jawa Pedesaan dan budaya militer yang kuat, Suharto dikenal sedikit bicara. Apa yang dikatakan, adalah apa yang dikerjakan, begitu pembawaannya.

Dari sekian waktu berjalannya kepemerintahan Orde Baru dapat dicatat pokok-pokok penting tonggak sejarah politik yang dianggap berpengaruh penting dengan eksistensi Kompas. Dengan berusaha tidak mengurangi makna sejarah peristiwa-peristiwa penting lainnya, dapat disebutkan halhak yang berdampak terhadap eksistensi Kompas sepanjang 1966-2012:

\section{a. Meninggalnya Bung Karno}

Praktis meskipun secara de facto era Sukarno sudah lewat, namun secara figur, Sukarno masih merupakan ancaman bagi supremasi kekuatan tandingan, khususnya dari politisi sipil terhadap stabilitas yang dibangun rejim militer Orde Baru. Baru setelah meninggalnya Bung Karno pada tanggal 21 Juli 1970, bisa dikatakan secara semiotik bahwa moral kelompok politik sipil, atau faksi ABRI selain Angkatan Darat sudah habis. Bapak Bangsa, sekaligus tokoh panutan mereka sudah tidak ada. Simbol pemersatu yang jadi junjungan berjuta pengagumnya ini pulang selama-lamanya.

Dewan redaksi Kompas kebetulan juga memilih untuk tidak terlalu vulgar dalam menurunkan tulisan-tulisannya. Situasi sangat berbeda dengan awal mereka terbit. 
Pada tahun 1970 praktis Angkatan Darat merupakan suatu kelompok yang kekuatannya semakin mendominasi Indonesia.

\section{b. Fusi Partai-Partai Politik Pada}

\section{Tahun 1973}

Pada tahun 1971 dilaksanakan Pemilihan Umum, Pemilu, pertama di era Orde Baru, dengan diikuti oleh 10 partai politik. Pemilu ini dimenangkan oleh Golongan Karya, Golkar. Kemudian guna memudahkan menguasai percaturan politik secara legal, pada tahun 1973 dikeluarkan himbauan untuk meringkas jumlah partai-partai yang ikut pemilu berikutnya. Caranya ialah dengan menggabungkan diri dengan partaipartai lain yang sejenis. Sebagai hasilnya maka jumlah partai yang ada tinggal dua yakni kelompok Islam di Partai Persatuan Pembangunan, PPP, dan pihak nasionalis, Kristen, dan Katolik di Partai Demokrasi Indonesia, PDI. Ditambah lagi dengan Golkar yang enggan mengaku sebagai Partai Politik. Semua kontestan dilarang untuk menggunakan dasar partai selain Pancasila. Kondisi ini artinya adalah terjadi penguatan di pihak Golkar-Angkatan Darat-Orde Baru karena isu-isu sentimen keagamaan atau isu kedaerahan yang bisa memicu loyalitas dukungan ditiadakan secara sistematik Tindakan lain yang diperhitungkan sebagai hal yang menguntungkan ialah dengan terbitnya UU No. 3 Tahun 1975 tentang kepengurusan partai-partai yang terbatas hanya sampai tingkat daerah tingkat dua, Kabupaten atau Kota. Kebijakan ini mempersulit PPP dan PDI untuk melakukan pembinaan kader, sekaligus mempersulit mereka mendapatkan pendukung di desadesa. Inilah mengapa kemudian muncul istilah massa mengambang, floating mass, untuk mendefinisikan sejumlah simpatisan yang tidak terorganisir secara resmi. Hal mana, selain kesempatan menggunakan jaringan birokrasi pegawai negeri yang wajib Golkar, yang kemudian membantu Golkar menang mudah di Pemilu berikutnya pada tahun 1977.

Fusi ini mempunyai dampak yang kuat bagi politik nasional. Bagi Kompas sendiri perkembangan dari hari ke hari semakin memaksa mereka untuk memilih menjadi sahabat Orde Baru atau memilih musnah. Dalam catatan sejarawan asing seperti John Roosa, Kompas adalah termasuk media independen di luar polarisasi komunis versus Angkatan Darat yang cenderung menyiarkan pemberitaan yang menguntungkan pihak Tentara Angkatan Darat, dengan seolah-olah menyembunyikan kekejamannya, di 
tahun-tahun awal Orde baru hinggga berakhirnya Orde Baru (Roosa, 2006, terjemahan Institut Sejarah Sosial Indonesia, 2008:30-31).

Kompas sendiri memilih untuk mengatakan bahwa slogan kerja mereka adalah, "menghibur yang papa, mengingatkan yang mapan" (St. Sularto:173-174). Pemberitaan yang mengutamakan jurnalisme fakta, dan menyajikan secara santun, tidak provokatif. Masalah-masalah suku, agama, ras, dan perbedaan yang ada di Indonesia jika tidak dikelola secara arif, dengan menempatkan kepentingan nasional di atas kepentingan pribadi dan kelompok, tak urung menjerumuskan masyarakat ke arah radikalisme ataupun chauvinisme. Keinginan untuk mengedepankan kepentingan pribadi atau golongan hendaknya diletakkan di bawah prioritas suatu kepentingan umum atau kepentingan masyarakat luas. Seperti itulah semangat jurnalisme Kompas yang bagi pihak penguasa baru merupakan media "teman".

\section{c. Pemberedelan Kompas Tahun 1978}

Sebagai buntut dari memanasnya politik nasional seusai peristiwa Malari 1974, dari waktu ke waktu gelombang aksi penentangan terhadap dominasi militer mulai terjadi di mana-mana. Mulai bulan
November 1977 aksi-aksi protes yang terjadi semakin mengerucut pada tuntutan Suharto mundur pada tahun 1978. Rangkaian peristiwa-peristiwa politik itu oleh hampir semua media diberitakan, dengan gaya masingmasing dari media yang memberitakan, termasuk Kompas. Meskipun cenderung berhati-hati namun kadang-kadang menurut pemerintah sajian Kompas selama beberapa waktu itu mulai kurang enak didengar oleh pemerintah. Seperti misalnya pemuatan tulisan di halaman depan pada terbitan bertanggal 16 Januari 1978, Kompas (dalam St. Sularto, 2011:12), "Kas Komkamtib Sudomo: Turun Ke Jalan Akan Ditindak Tegas". Juga penggalan dari tajuk rencana Kompas di hari itu juga, Kompas (dalam St. Sularto:2011:12), "Kita diminta terbuka dan jujur karena memang terlibat berbagai kepentingan status quo di sini. Ini bisa mempengaruhi pandangan obyektif dan subyektif, bisa mengaburkan sikap kenegarawanan". Ada semacam tindakan preventif, meski cenderung represif yang diambil oleh militer yang mendukung Presiden untuk menertibkan corong suara media.

Selama Orde Baru berkuasa, berkali-kali kompas mendapatkan teguran atau peringatan. Teguran itu 
bahkan kadang-kadang disertai dengan ancaman. Hingga pada akhirnya pada tanggal 21 Januari 1978 Kompas beserta beberapa media yang lain dibredel oleh Orde Baru. Namun pada tanggal 5 Februari 1978, Kompas menyetujui tawaran pemerintah untuk menandatangani suatu surat berkepala surat tanggal 28 januari 1978, tentang permintaan maaf dan kesetiaan terhadap pemerintah Orde Baru (St. Sularto, 2011:11-13).

Terdapat empat syarat yang menyertai ijin terbit kembali dari pemerintah Orde Baru, yakni: pertama, tidak menulis tentang keluarga Presiden Suharto dan asalusul kekayaan keluarganya; kedua, tidak akan mempersoalkan dwifungsi ABRI; ketiga, tidak akan menulis tentang masalah-masalah yang berkaitan dengan suku, agama, ras, dan antar golongan; keempat, tidak akan menurunkan tulisan yang memperuncing konflik. Empat syarat ini secara sistemik berpotensi membatasi keleluasaan Kompas berekspresi. (St. Sularto, 2011:24).

Namun Kompas sendiri menegaskan bahwa sikap Kompas terhadap penguasa adalah independen. Artinya mengambil jarak terhadap pemerintah dan setiap lembaga kekuasaan dan siapa saja yang mau menguasainya. Untuk dapat melakukan hal itu, Kompas harus siap menghadapi kecurigaan, tekanan, dan ancaman dari manapun juga (St. Sularto, 2011:147).

Kompas memilih manut kepada Orde Baru dengan alasan cara bertahan hidup dan terus membawakan amanat hati nurani rakyat,meski secara terselubung jika kebetulan berbenturan dengan kepentingan pemerintah. Sikap Kompas ini sembari diwarnai beberapa kali tindakan jurnalistik yang menyerempet-serempet sensor Orde Baru. Pendeknya, tak jauh beda dengan Bung Karno yang memilih terbuka dan bekerjasama dengan pihak penjajahan Jepang semata-mata demi alasan pilihan taktik berjuang dan bertahan hidup, mengingat begitu berkuasanya pemerintahan militer Jepang yang menduduki Indonesia, pada kurun waktu tahun 1942-1945.

\section{Pertumbuhan Pesat Selama Tiga Dasawarsa Orde Baru}

Sejak terbit perdana pada tahun 1965 hingga akhir masa Orde baru tahun 1999 Kompas tercatat menorehkan sejumlah keberhasilan yang luar biasa baik dari segi pengaruh maupun dari segi bisnis media massa. Dimulai dari kesuksesannya mendapat jumlah pembaca pelanggan dan pengiklan, pada tanggal 2 Februari 1970, PK Ojong 
mengambil kebijakan untuk melakukan diversifikasi usaha dengan cara membuka toko buku Gramedia di Jalan Gadjah Mada, Jakarta Pusat, kemudian di tahun 1972 meresmikan penggunaan percetakannya sendiri di Jalan Palmerah Selatan, Jakarta; di mana sebelumnya masih menumpang di percetakan Keng Po. Ojong kemudian mendirikan usaha radio Sonora pada tahun 1972 juga. Selain itu grup Kompas Gramedia juga mendirikan banyak unit usaha lain yang dijadikan satu grup, antara lain Hotel Santika, Penerbitan Grasindo, Penerbit Kompas, Penerbit KPG, Penerbit Gramedia, pabrik kertas, dan lain sebagainya. Banyak aset, baik berupa modal uang, tanah-bangunan, alat, dan sumber daya manusia yang dimiliki grup Kompas Gramedia, suatu kelompok usaha yang awalnya berasal dari kesuksesan harian Kompas merebut hati pembaca, dan mitra pelaku usaha yang mempercayakan kerjasama pariwaranya pada harian ini. Singkatnya, manajemen Kompas sukses melakukan investasi secara berkesinambungan dengan menggunakan keuntungan yang didapat dari kesuksesan harian Kompas.

Namun dalam hal ini yang lebih jadi penekanan adalah mengenai harian Kompas. Pembahasan sengaja dibatasi dalam kaitan eksistensi harian Kompas dalam melewati kurun waktu penting dalam pembabagan yang telah disusun.
Kompas dibaca oleh kalangan menengah ke atas. Hasil angket pembaca kompas 2004 misalnya menyebutkan, lebih dari 60 persen pembacanya adalah lulusan perguruan tinggi dan 30 persen pembacanya berpenghasilan paling sedikit Rp.2.250.000,-. Koran ini menjadi standar capaian bisnis surat kabar. Memang tidak berlebihan jika kemudian timbul suatu jargon, belum koran kalau belum baca Kompas.

Kesuksesan Kompas, tidak hanya sekedar bertahan hidup di era represif, namun juga sukses dalam artian yang seluas-luasnya barangkali tidak pisa dipisahkan dari sinerginya duet PK Ojong dan Jakob Oetama. Jika PK ojong terkenal berwatak rasional, keras, dan tegas, serta memiliki kecakapan dalam hal bisnis. Sebaliknya Jakob adalah gambaran suatu watak yang tengah, bijaksana, cenderung berhati-hati, bersikap komprehensif, cerdas, dan bisa diartikan cerdas atau malahan pengecut, tergantung subyektifitas yang memandangnya (St. Sularto, 2011:16). Maka, paktis semenjak meninggalnya PK Ojong pada tanggal 2 Juni 1980 nama Kompas artinya merujuk pada seorang Jakob Oetama. Berikut adalah hal-hal yang bisa dilihat dari kiat Kompas menjalani aktivitas pers mereka di era Orde Baru:

\section{a. Enam Strategi Jakob Oetama}

Leo Batubara (dalam St. Sularto, 2011:144-146) 
mengemukakan alasan yang lebih terperinci perihal kesuksesan Kompas. Menurut Leo keberhasilan Kompas bersumber dari keberhasilan semua jajaran dalam membangun profession culture: taat asas kepada visi dan nilai-nilai serta enam strategi pemenangan pergulatan. Enam strategi itu antara lain:

\section{Pertama, professional} competence memenangkan pasar. Taktik yang dilaksanakan ialah rekrutmen yang selektif dengan bantuan institusi profesional, mengalokasikan sejumlah besar dana untuk membangun knowledge journalist dan staf bisnis profesional dengan program training dan retraining bagi SDM-nya, memanfaatkan kemampuan para pakar, kolumnis sebagai kontributor dalam bidangnya.

Kedua, yang dikembangkan adalah produk bukan menjual dusta atau fitnah. Kompas menjauhkan diri dari berita yang spekulatif, provokatif, dan pembunuhan karakter. Dalam melakukan kritik disampaikan secara santun.

Ketiga, integrasi misi ideal dengan misi bisnis. Bagaimana keseriusan Kompas untuk mengemas suatu konten yang berbobot namun tetap memenuhi kelayakan dalam hal bisnis menarik untuk dipelajari dalam studi lanjutan mengenai Kompas.

Keempat, mengintegrasikan kepentingan karyawan dan kepentingan perusahaan dengan serasi. Sempat terjadi gesekan dengan serikat karyawan namun Kompas bisa mengatasinya. Bagi Kompas kepentingan perusahaan adalah eksistensi, untung, dan berkembang. Sedangkan kepentingan karyawan sebagai seorang business man adalah menyumbang dan mendapat imbalan uang, serta perasaan mental positif yang tertantang.

Kelima, mengupayakan efisiensi, mengacu pada minimalisasi usaha atau biaya, dan efektifitas, mengacu pada ketercapaian tujuan, dengan baik. Jakob dan grup Kompas dalam memperjuangkan diri sebagai the biggest dan the most credible multimedia jauh dari ambisi memonopoli informasi.

Keenam, mengupayakan kepuasan konsumen dengan serius. Di antaranya Kompas menyelenggarakan lembaga penelitian dan pengembangan, litbang Kompas, menyelenggarakan riset berkala, melakukan jajak pendapat, dan menjalankan ombudsman.

\section{b. Peka Terhadap Jaman}

Cetakan harian Kompas itu bagus, jelas, tata letak serta 
pewajahannya berkarakter serius, cerdas, dan profesional. Kertas koran yang digunakan Kompas sangat berkualitas. Jika dibandingkan dengan Jawa Pos tentu jauh lebih bagus kualitas cetak harian Kompas. Apalagi jika dibandingkan dengan kualitas cetak Pos Kota atau Memorandum, sangat jauh sekali disparitas kualitasnya.

Jika pada awal cetaknya hanya berupa empat halaman hitam-putih, maka pada tahun-tahun berikutnya tampilan Kompas mengalami penyempurnaan-penyempurnaan yang diaharapkan untuk terus mengup to date Kompas. Sebagai catatan, dalam kaitannya sebagai media koran dengan cakupan nasional harian Kompas yang dulu kerap diolok dengan julukan koran kesiangan, koran telat datang, atau kompas morgen, menyikapi dengan mengusahakan suatu percetakan jarak jauh. Dimulai dengan di Bawen, Jawa Tengah, pada tanggal 1 September 1997, dilanjutkan dengan kota-kota lain seperti Makassar, Surabaya, Palembang, Banjarbaru Kalimantan Selatan, dan lain-lain. Dari sini efisiensi waktu dapat ditingkatkan dalam rangka pendistribusian koran ke seluruh wilayah nusantara.

\section{Kompas di Era Orde Reformasi}

\section{Orde Reformasi}

\section{a. Definisi}

Orde Reformasi adalah istilah untuk menyebut tata pemerintahan sesudah berakhirnya orde baru yang mengadakan perombakan sistem yang lama ke arah sistem demokrasi. Secara umum orde reformasi dimulai dengan berakhirnya kekuasaan Suharto pada tanggal 20 Mei 1998 (Kamus Besar Bahasa Indonesia, 2008:1).

\section{b. Latar belakang}

Pada awal-awalnya Orde Baru mendapat apresiasi positif dari banyak lapisan masyarakat untuk melakukan pembenahanpembenahan terhadap kemerosotan ekonomi Orde Lama, beserta otoriternya gaya politik Sang Pemimpin Besar Revolusi, Sukarno. Kekuasaan Orde Baru memperlihatkan perubahan yang jauh lebih baik dalam bidang sarana prasarana fisik. Indonesia yang segera sesudah berakhirnya era Sukarno memperbaiki hubungan dengan negara-negara maju melaksanakan pembangunan dengan modal pinjaman dari negara donor.

Didapat sejumlah kepercayaan dari dalam maupun 
luar negeri. Kesulitan ekonomi di tahun penghujung Orde Lama segera digantikan dengan gegap gempita pelaksanaan program pembangunan bermodal besar di awal pemerintahan baru. Namun, sayang jikalaupun ada peningkatan kesejahteraan yang terwakili oleh angka-angka raihan pembanguna, dari sisi pemerataan belum bisa dikelola dengan baik. Terdapat kesenjangan yang mencolok antara sosial-ekonomi atas dengan rakyat jelata. Maka, bilapun ada pertumbuhan ekonomi yang terjadi sebenarnya adalah sebagian kecil saja yang memiliki bagian kemajuan ekonomi tadi. Sayangnya kelompok Orde Baru terus menerus mempertahankan kekuasan dengan semakin berperilaku otoriter. Nilai-nilai demokrasi yang sedianya dijadikan acuan pola kerja penyelenggaraan negara, sebagi konsekuensi kritik mereka terhadap Orde Lama, pada gilirannya justru mereka kebiri sendiri. Hal ini setidaknya bisa dilihat dari indikator berikut: 1) Pengekangan kebebasan berpolitik, 2) Pengekangan kebebasan pers, 3) Pemusatan kekuasaan pada Golkar, Militer, dan Pengusaha kroni Suharto.
Pada tahun 1996 suasana politik nasional mulai memanas. Golongan Karya yang sejak tahun 1970-an memenangkan pemilu dengan mudah mulai dikritisi secara terbuka oleh para oposannya, baik dari kalangan politisi maupun akademisi kampus. Kultur senayan yang biasanya adem-ayem karena terkondisikan, kini mulai ramai mendapat tekanan dari masyarakat yang tidak puas. Hasil pemilu 1997 yang, lagi-lagi, dimenangkan Golkar dipandang kental dengan kecurangan sistematis. Masyarakat semakin mendesak untuk dilaksanakannya perubahan di bidang politik, ekonomi, demokratisasi dalam kehidupan sosial serta dihormatinya hak asasi manusia. Pada masa ini tenar dikenal istilah KKN, korupsi, kolusi, nepotisme, yang pada dasarnya adalah suatu stigma negatif yang dilekatkan kepada pemerintah Orde Baru.

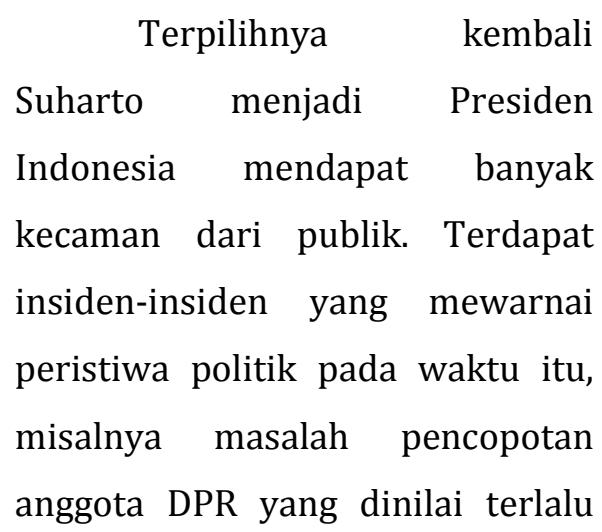


vokal. Dari kalangan akademisi, masyarakat tidak mudah melupakan nama Sri-Bintang Pamungkas, seorang dosen Fakultas Teknik Universitas Indonesia yang diberhentikan status pegawai negerinya sehubungan dengan tuduhan pelecehan nama baik Kepala Negara. Di mana pada sebuah kunjungan kenegaraan Suharto ke Jerman terjadi demonstrasi kalangan mahasiswa Indonesia di sana untuk menyambutnya. Hal ini di jaman Orde Baru sangatlah langka terjadi, mengingat sedemikian kuatnya Presiden Suharto dalam membangun imperium kekuasaannya. Bisa dikatakan, memang Suharto terlalu kuat untuk bisa roboh dalam satu pukulan. Tetapi setidaknya, cuatan kasus politik semacam Bintang ini sukses menjadi nyala pemantik api gerakan pembaharuan dalam skala yang lebih masif.

Krisis ekonomi di tahun 1998, inflasi tinggi, kemiskinan, pengangguran. Tata kelola birokrasi pemerintahan yang korup, pengekangan kebebasan berpolitik, pengekangan pers. Pemusatan kekuasaan di Golongan Karya, militer, dan pengusaha kroni Suharto merupakan suatu latar belakang yang ada dalam menghasilkan suatu desakan reformasi. Puncaknya ialah pidato pernyataan mundur dari jabatan kepresidenan yang dibacakan Suharto, pada tanggal 21 Mei 1998 di Jakarta.

\section{Tonggak Peristiwa-Peristiwa} Politik Penting

Turunnya Suharto pada tanggal 21 Mei 1998 merupakan satu peristiwa politik terpenting dalam sejarah reformasi. Tanggal ini merupakan titik tolak dimulainya masa baru, masa yang diharapkan sejumlah pihak untuk diadakan perubahan-perubahan mendasar dalam negara Indonesia.

Ada dua kejadian penting yang bisa dicatat dalam kurun waktu 1998-2012 terkait reformasi. Dua hal itu yaitu:

\section{a. Amandemen UUD 1945}

Amandemen UUD 1945 diselenggarakan sebanyak empat kali. Pertama pada Sidang Umum MPR Oktober 1999. Kedua, pada Sidang Tahunan MPR Agustus 2000, ketiga pada Sidang Tahunan MPR Oktober 2001, dan perubahan keempat pada Sidang Tahunan MPR Agustus 2002. UUD yang telah mengalami empat kali perubahan inilah yang hingga kini digunakan. Terjadi 
perubahan secara total dan mendasar yang terjadi sebagai konsekuensi adanya amandemen UUD ini, misalnya penurunan derajat lembaga MPR sebagai lembaga tertinggi, kini menjadi lembaga tinggi negara sejajar dengan Presiden. Perubahan juga terjadi dengan digunakannya mekanisme pemilihan umum secara langsung untuk memilih Presiden Republik Indonesia.

\section{b. Pemilu Langsung}

Banyak perubahan besar dalam konstitusi sehubungan dengan dilaksanakannya empat kali perubahan. Salah satu perubahan aturan main yang paling menarik perhatian masyrarakat adalah dalam hal tata cara pemilihan Presiden Republik Indonesia. Jika sebelumnya Presiden dipilih dan diangkat oleh Majelis Perwusyawaratan Rakyat, MPR, sebagai lembaga tertinggi negara, namun seusai adanya amandemen ke empat pada tahun 2002 maka pemilihan Presiden dilakukan secara langsung oleh segenap rakyat yang memiliki hak suara.

\section{Dampak Perubahan Politik}

Ada sejumlah dampak akibat perubahan politik yang secara langsung, maupun tidak langsung berimbas pada eksistensi Kompas. Beberapa hal itu antara lain:

\section{a. Kebebasan Pers, Saingan Usaha}

\section{Bertambah}

Kemudahan dalam perijinan telah membuat pemain dalam usaha di bidang media massa meningkat drastis. Hal ini adalah berita menggembirakan, namun sekaligus juga adalah tantangan bagi Kompas untuk menanganinya.

i) Persaingan Dengan Sesama Koran Dalam pentas nasional Kompas bersaing dengan Jawa Pos, Media Indonesia, Republika, Sinar Indonesia. Kesemuanya diterbitkan di Jakarta, namun dalam prakteknya di luar Jakarta Koran-koran itu juga bersaing dengan koran-koran daerah yang membludak. Suatu kondisi yang oleh Jalaluddin Rakhmat (dalam Hanif Hoesin, 2012:11) disebut sebagai suatu euforia kuda. Di mana pada masa sebelumnya seolah-olah dunia pers itu sepi, tenang, tidak ada gejolak, namun ketika dibuka kebebasan yang luas industri pers itu seperti kuda liar lepas kandang. Kuda itu pencilakan kemana-mana dengan tidak karu-karuan.

Dalam kalimat yang lebih ekstrem, kebebasan pers di masa 
Orde Reformasi itu telah mendorong pers bebas menggosip, menuliskan apa saja kecuali kebenaran. Namun sebagai pemain lama, Kompas mempunyai ketahanan budaya untuk tetap melaksanakan suatu karakter jurnalisme yang humanis beriman.

ii) Persaingan Dengan Bentuk Media Massa Lain

Dalam dunia yang telah sangat berubah, persaingan informasi rupanya tidak hanya terjadi dari satu jenis media saja. Namun bisa saja antar satu media yang satu dengan jenis media yang lain saling memakan. Memakan tidak hanya basis pembaca pelanggan, tetapi juga target rekanan pemasang iklan.

Sebagai contoh, bila dahulu kala setiap keluarga berada bisa dipastikan berlangganan koran, namun di jaman internet seperti sekarang bisa jadi justru orang yang maju sudah tidak lagi semata-mata berlangganan koran cetak. Keberadaan koran cetak mungkin saja sudah digantikan oleh versi digital koran atau majalah, atau situs-situs berita on-line. Situs, koran atau majalah versi digital itu sendiri dengan mudah bisa diakses dari gadget-gadget, misalnya smartphone atau Apple Ipad yang banyak dimiliki orang Indonesia di era reformasi dewasa ini. Memiliki sifat portabel, memiliki kecepatan untuk tersampaikan pada audiens adalah salah satu keunggulan media massa berbasis teknologi internet; misal hasil pertandingan sepakbola Olimpiade antara Spanyol dan Honduras yang baru saja berakhir bisa langsung diakses orang Indonesia hampir pada menit yang sama peluit wasit dibunyikan, melalui bantuan situs berita olahraga Livescores, www.livescores.com

\section{b. Kekuasaan Media Massa Berada}

\section{Pada Pemilik Dan Selera Pasar}

Isu lain yang muncul di era reformasi dewasa ini adalah di mana kekuatan media massa bergeser dari pemerintah ke pemilik atau selera pasar. Dahulu kala wartawan politik di lapangan ketika sudah menyelesaikan hasil liputan biasanya harap-harap cemas apakah beritanya bisa diloloskan pihak berwajib atau tidak. Masalahnya editor suatu surat kabar merupakan binaan dari aparat berwenang. Pada kurun waktu dewasa ini pemilik media-lah pusat dari segala 
keputusan suatu kebijakan redaksi berita dalam surat kabar. Misal Surya paloh dengan Media Indonesia-nya, sulit dimungkinkan suatu laporan jurnalistik yang berani menjelek-jelekkan Partai Nasdem, Partai yang didirikan oleh Surya Paloh.

Terkait dengan selera pasar, maksudnya adalah seringkali selera masyarakat luas secara umumnya lebih rendah dari standar idealisme yang dimiliki oleh dewan redaksi. Pada era reformasi, berita-berita mengenai gosip remeh-temeh dari artis yang kawin-cerai jauh lebih menantang untuk diikuti ketimbang lanjutan kasus Lapindo Brantas di Sidoarjo. Itulah mengapa jika terlalu memburu idealisme bisa-bisa suatu media kehilangan pembaca, otomatis juga pengiklan. Tetapi jika terlalu memburu selera pasar, hal yang paling mudah dijual adalah eksploitasi daya tarik seksual, kekerasan, dan pertunjukan hiburan belaka.

Koran seperti Republika, Kompas, dan Media Indonesia telah memiliki karakter yang teruji dengan godaan selera pasar yang rendah. Jika seolah-olah ada paksaan antara memilih idealisme jurnalisme dan selera pasar maka media-media tersebut memilih jalan alternatif, yakni jalan untuk terus berkarakter dan aktif mengedukasi pasar sehingga masyarakat memiliki peningkatan kualitas selera baca. Barangkali inilah terapan dari satu fungsi pers yakni to educate pembacanya, tidak sekedar mengeksploitasinya.

\section{c. Jurnalisme Bodrex}

Dalam masa reformasi ini praktek-praktek reportase politik di lapangan dikotori oleh adanya fenomena jurnalisme Bodrex. Yaitu fenomena munculnya wartawanwartawan bermental pemeras. Dilatari oleh kebebasan pers, kenaikan gengsi dan posisi tawar wartawan beberapa dari mereka menggunakan kesempatan untuk melakukan pemerasan dalam pelaksanaan profesinya di lapangan.

Jurnalis Bodrex, kata Bodrex ini berasal dari salah satu obat pusing, atau sakit kepala, yang terkenal di Indonesia. Hal ini relevan dengan memusingkannya paraktek wartawan-wartawan pemeras di tanah air kita ini.

Wartawan Bodrex sendiri kadang-kadang tidak berasal dari suatu lembaga pers yang mapan. Bahkan ada yang kantor saja masih menumpang di tempat orang. Modal mereka hanya kartu pers dan kamera digital seadanya. Pertanyaan 
berikutnya, lalu mengapa mereka bisa melaksanakan pemerasan, misalnya ke institusi pemerintahan? Ini tak lain karena diakui-tidak diakui ada penyelewengan yang masih berjalan di tempat tersebut. Inilah celah yang bisa dimanfaatkan para Bodrex untuk menakut-nakuti pegawai institusi yang bersangkutan, sekaligus menegoisasikan berapa besar uang tutup mulut yang layak mereka dapatkan.

\section{d. Strategi Dan Taktik Kompas}

Ada hal-hal strategis yang dilakukan oleh Kompas untuk menyiapkan diri menghadapi situasi baru di era reformasi. Beberapa langkah itu menurut Leo Batubara (dalam St. Sularto: 2011:144-146) antara lain adalah: Pertama, penguatan SDM profesional. Kedua, mengutamakan kualitas pemberitaan dan tampilan. Ketiga, integrasi misi ideal dengan misi bisnis. Keempat, mempertemukan kepentingan perusahaan dan kepentingan karyawan. Kelima, efisien efektif, dan keenam, mengupayakan kepuasan konsumen dengan serius.

Kompas melakukan perbaikan tampilan korannya secara serius, dan dinamis, terus-menerus. Seorang konsultan desain kelas dunia, Mario Garcia dari Amerika Serikat, tahun 2005 diminta mendadani wajah Kompas, sehingga Kompas tampil lebih modern dan manis.

Dalam situs resmi Kompas Gramedia (Kompas Gramedia, 2012:1), Konsep visual thinking merupakan isu utama dari konsep yang ditawarkan Mario Garcia. Gambar, infografik, ilutrasi, menjadi hal yang sangat penting dari keseluruhan wajah surat kabar. Seorang wartawan di lapangan, harus bisa meulis dan memvisualiasaikan tulisannya agar lebih menarik karena lebih manis. Bersamaan dengan perubahan wajah tersebut, diperkenalkan lembar khusus iklan yang diberi nama Klasika. Diharapkan lembar khusus Klasika ini memudahkan pembaca mengakses informasi niaga yang ditampilkan, sekaligus tentu saja sebagai salah satu sumber pendapatan terbesar dari operasional koran, langkah ini tentu diharapkan bisa meningkatan efektivitas pendapatan perusahaan.

Meninjau dari segi taktis di lapangan, ada beberapa hal yang bisa diamati dari pemasaran Kompas. Hal itu antara lain: a) Harga jual koran yang murah. Apabila dibandingkan dengan kompetitor 
ketatnya yaitu Jawa Pos, harga jual Kompas justru di bawahnya. Jika eceran di Madiun, Jawa Timur Jawa Pos adalah Rp. 3.500,- sampai dengan Rp. 4.000,- maka Kompas hanya mengenakan harga eceran sebesar Rp. 3.000,-; b) Jumlah halaman dan kertas koran yang menarik; c). Isi koran sangat berkualitas. Suatu kebanggaan bagi kaum akademisi atau kaum politisi apabila tulisannya sudah tampil di Kompas; d) Gaya bahasa Kompas santun dan cerdas. Penggunaan bahasa Indonesia di harian Kompas sangat apik dan sesuai kaidah berbahasa yang benar; e) Gaya promosi Kompas mengutamakan aktivitas below the line. Kompas tidak menggunakan media-media seperti TV atau majalah untuk mengiklankan diri.

Cara memahami keberhasilan Kompas menjadi pemimpin di industri surat kabar memang bisa dari banyak sisi. Tulisan ini dibuat untuk membantu memberikan beberapa catatan dan analisa perihal dunia politik dan kaitannya dengan eksistensi koran Kompas. Dibutuhkan banyak literatur pendukung untuk melengkapi tulisan pengantar mengenal sejarah politik, koran
Kompas, dan relasi saling terkait antar keduanya.

\section{Simpulan}

Hal yang harus diingat bahwa, keberlangsungan suatu usaha pers, eksistensi pers, tidak hanya terpengaruh dari faktor internal perusahaan, seperti kecakapan wartawan, atau kecakapan dewan redaksi. Keberlangsungan suatu usaha pers juga terpengaruh dari faktorfaktor eksternal di luar perusahaan yakni: situasi ekonomi, selera konsumen, kepentingan pemilik perusahaan pers sebagai pemilik modal, termasuk juga faktor eksternal lain yang tidak kalah pentingnya yakni kebijakan politik pemerintah. Indonesia sepanjang kemerdekaannya mencatat sejarah panjang mengenai pembatasan kehidupan pers. Masing-masing penguasa memiliki dalih atas kepentingannya masing-masing. Hal ini selaras dengan pengertian bahwa suatu kebijakan politik tidaklah terlahir di ruang hampa. Kebijakan politik adalah produk suatu dinamika aksi reaksi antar variabel yang terlibat di dalamnya.

Kajian pustaka dengan metode historis yang digunakan dalam penelitian ini menyimpulkan pemahaman sebagai berikut:

\section{Kompas di Era Orde Lama}

Era Sukarno dengan pembatasan pers ala demokrasi terpimpin mengharuskan pemimpin membina 
langsung pers demi keberhasilan propaganda anti neo kolonialisme, neo imperialisme. Kompas lahir di penghujung berakhirnya Orde Lama. Terjadi perebutan pengaruh, atau perebutan kekuasaan yang sengit antara kelompok-kelompok yang ada di tanah air. Dinamika yang terjadi menempatkan tiga kelompok utama sebagai pihak yang paling dominan menggulirkan sejarah politik di tanah air, Kelompok Bung Karno, Militer Angkatan Darat, dan pihak komunis.

Latar belakang pendiri dan pemimpin Kompas berasal dari unsur intelektual Katolik. Terindikasi dua hal mengenai jati diri Kompas: Kompas yang menyelenggarakan suatu pers Katolik anti komunis, dan sebagai Kompas yang merupakan koran pendukung ABRI. Mereka membangun sejarah Kompas di Jakarta. Ibu Kota suatu negara yang sangat sentralistik. Indonesia adalah Jawa, dan Jawa adalah Jakarta. Maka strategis sekali posisi Kompas dalam bertindak dalam kapasitasnya sebagai suatu pers yang memihak dan mampu mempengaruhi opini orang banyak.

Dari sudut pandang Kompas sendiri mereka menyampaikan bahwa Kompas merupakan sebuah koran independen. Koran yang menghargai kemajemukan, kerjasama, dan berwatak nasionalime Pancasila. Ini seperti yang diutarakan oleh Jakob Oetama, dan tim redaksi Kompas yang lain dalam berbagai kesempatan berbicara. Ini juga tertera pada nilai-nilai perusahaan, company value, Kompas Gramedia (Agung Adiprasetyo, 2012:1).

\section{Kompas di era Orde Baru}

Orde Baru merupakan suatu pemerintahan dengan supremasi tunggal di pihak Suharto. Suharto melarang adanya suatu ekspos atau kritik terhadap diri Presiden dan kelompok utama pendukungnya.

Suharto memiliki kekuatan penuh dengan dukungan dari ABRI, khususnya Angkatan Darat, dan dari legitimasi resmi suatu partai politik Golongan Karya. Kehidupan politik di era Orde Baru bersifat statis. Kontestan Pemilu selain Golkar hanya berstatus sebagai pelengkap penderita ketimbang sebagai mitra tanding yang sepadan. Golkar memenangkan pemilu secara telak dalam enam kali pemilu sepanjang tahun 19661998. Orde Baru menerapkan suatu kebijakan pers yang otoriter. Pemerintah, melalui Departemen Penerangan, menerapkan serangkaian kegiatan pengawasan terhadap pers Indonesia termasuk dengan cara memonopoli pasokan dan distribusi aneka macam tinta cetak sebagai bahan utama industri pers. Departemen ini mengatur sederetan surat ijin prasyarat produksi. Dari hal-hal tersebut bisa diambil kesimpulan bahwa Orde Baru 
mewajibkan suatu pers yang patuh atau jika tidak pers tersebut akan dibunuh.

Kompas melaksanakan suatu konsep jurnalisme kepiting dalam merespon kebijakan otoriter Orde Baru terhadap kebebasan pers. Konsep jurnalisme kepiting adalah suatu taktik main aman dan penuh kehati-hatian dalam memberitakan sesuatu yang menjadi hak rakyat untuk diketahui, namun tetap dalam batas agar Bapak tidak marah.

Ben Anderson (dalam Hill, 2011:98), menyikapi ini dengan melabel Kompas sebagai koran Orde Baru sejati. Kompas dipandang terlalu menjunjung tinggi kehati-hatian dan secara sadar memilih jadi moderat setiap mengupas masalahmasalah politik yang sensitif.

\section{Kompas di era Reformasi}

Kelonggaran

kebijakan

berpendapat dan kebebasan pers oleh pemerintah di era Orde Reformasi disikapi Kompas dengan tidak berlebihan. Pengalaman di era sebelumnya membantu memperkuat ketahanan mereka untuk bisa memanfaatkan kebebasan pers secara proporsional. Kompas fokus untuk memperkuat kesinambungan perluasan skala usaha mereka. Dari terbit perdana, 28 Juni 1965, dengan tampilan empat halaman hitam-putih dan oplah hanya 4.800 eksemplar pada tahun-tahun awal penerbitannya, hingga di tahun 2000-an pada era reformasi tiras Kompas sudah mencapai 500.000 eksemplar dengan tingkat keterbacaan diperkirakan mencapai $\quad 1.850 .000$ orang yang membaca Kompas tiap harinya (Kompas Gramedia, 2012:1).

Dari semula sebuah surat kabar nasional yang punya beberapa usaha pendamping, Kompas akhirnya mereorganisasi diri menjadi sebuah grup usaha Kompas Gramedia yang memiliki banyak unit usaha. Grup Kompas Gramedia menjadi salah satu imperium industri pers di Indonesia dalam catatan seorang David T. Hill, Indonesianis terkemuka dari Murdoch University, Perth, Australia (Hill, 2011:99).

David Hill juga mencatat bahwa dibandingkan dengan sejumlah surat kabar lain yang sukses di pasaran, bendera Kompas-lah yang paling lama berkibar sepanjang perjalanan sejarah. Kompas amat jarang mengalami pencabutan ijin. Kelompok Kompas Gramedia telah menjalin relasi yang erat dengan sejumlah institusi media milik pemerintah. Secara umum hubungan ini kadang harus memaksa Kompas memilih untuk terus-menerus menjaga tulisan mereka agar tidak melampaui batas. Di bawah kendali Jakob Oetama sebagai pendiri dan pemimpin tertingginya, pihak manajemen tidak segan-segan mendisplinkan jurnalis-jurnalisnya, bahkan menutup sejumlah terbitan daripada mengambil resiko berhadap- 
hadapan dengan pemerintah atau reaksi masyarakat (Hill, 2011:101). \

Sebagai catatan, surat kabar Kompas dalam struktur organisasi Kompas Gramedia ditempatkan sebagai salah satu unit usaha mereka di bawah Direktur Utama perusahaan Kompas Gramedia. Di mana pihak direksi bertanggung jawab terhadap Jakob Oetama dalam kapasitas Jakob sebagai Presiden Komisaris Kompas Gramedia.

\section{Saran}

Berdasar pada simpulan yang didapatkan dari kajian sejumlah sumber, disarankan beberapa hal guna menjaga eksistensi Kompas untuk terus bisa tampil di depan. Pertama, menjaga karakter sebagai koran yang memposisikan diri sebagai koran orang pintar dan mapan. Pemposisian diri, positioning, yang tepat dan konsisten membedakan diri dari pesaing differentiatie, adalah prinsip dasar ilmu manajemen pemasaran modern yang relevan untuk digunakan Kompas.

Kedua, Kompas hendaknya tetap dalam slogan menjadi media pengemban amanat hati nurani rakyat. Amanat ini termasuk juga nurani kolektif anak bangsa untuk bersatu-padu, saling tolongmenolong, dan bekerjasama di segala bidang pembangunan. Unsur kemajemukan penyusun negara Indonesia disikapi oleh Kompas dengan tetap mengedepankan penghormatan atas prinsip kesetaraan, tenggang rasa, dan saling menghormati. Kompas tidak terjebak untuk menciptakan suatu gesekan horisontal di masyarakat. Alih-alih, bersifat agamis atau partisan, meskipun para pendiri dan orang penting di Kompas berasal dari kaum Katolik namun justru secara fakta, nasionalisme Kompas sangat terasa betul merekatkan segala potensi bangsa untuk bersatu membangun negeri demi hari esok yang lebih baik.

Ketiga, Kompas hendaknya melibatkan diri pada aktivitas komunikasi dua arah secara lebih intens. Surat kabar, secara tradisional memang lebih bersifat komunikasi satu arah, yakni penyampaian isi materi dari dewan redaksi kepada pembaca. Kesertaan pembaca pada surat kabar sangatlah terbatas, di mana hanya sebatas keikutsertaan dalam kuis Teka Teki Silang, pengiriman berita, atau artikel, maupun semacam titipan keluhan. Masih ada banyak cara baru untuk memperkuat antusiasme pembaca agar tidak pernah melepaskan diri untuk melanggan harian nasional ini. Hal baru yang bisa ditempuh misalnya, membentuk klub pembaca atau klub pelanggan dan memberikan insentif yang layak terhadap pembaca yang loyal, bisa dalam bentuk piagam atau medali. Hemat kata, setiap hal baru selalu akan dikreasi oleh mereka yang selalu berjiwa besar dan berwatak optimis. Untuk itu layak distimulus, dengan imbalan tertentu, setiap langkah proaktif dari pemerhati Kompas. 


\section{Daftar Pustaka}

Adams, Cindy. 1965. Terjemahan oleh Syamsu Hadi. Bung Karno, Penyambung Lidah Rakyat Indonesia. 2011. Jakarta: Yayasan Bung Karno

Agung Adi Prasetyo. 2012. Mengenal Nilai Kompas Gramedia (online), (http://www.kompasgramedia.com/a boutkg/ceomessage, Diunduh 14 Maret 2012)

Amien Raies. 2008. Agenda mendesak Bangsa, Selamatkan Indonesia. Yogyakarta: PPSK Press

Ana Nadhya Abrar. 2011. Analisis Pers, Teori Dan Praktek. Jogja: Cahaya Atma Pusaka

Bambang Purwanto. 2011. Reality and Myth in Contemporary Indonesian History. Jurnal Humaniora (Online), Volume XIII, No. 1, (http://i-lib.ugm.ac.id, Diunduh 8 Maret 2012)

Britannica, Encyclopedy 2012. Newspaper (online),

(http://www.britannica.com/

Ebchecked/topic/

413113/newspaper, Diunduh 24 Maret 2012)

Chomsky, Noam \& Herman, Edward S. 2002. Manufacturing Consent, The Political Economy Of Mass Media. New York: Pantheon Books

Dahlan Iskan. 2011. Hidup Bahagia Jakob Oetama (online). (Error! Hyperlink reference not valid., Diunduh 21 Februari 2012)

Elson, R.E. 2001. Suharto, Sebuah Biografi Politik. Terjemahan oleh Satria Wahono dan IG Harimurti Bagoesoka. Jakarta: Pustaka Minda Utama

Hanif Hoesin. 2012. Selintas Sejarah Kebebasan Pers Di Indonesia (online), (http://kominfo.go.id, Diunduh 31 Juli 2012)

Helius Sjamsudin. 2007. Metodologi Sejarah. Yogyakarta: Penerbit Ombak

Hill, David T. 1995. Pers Di Masa Orde Baru. Terjemahan oleh Gita Widya Laksmi Soerjoatmojo. 2011. Jakarta: Yayasan Obor Indonesia
Ikrar Nusa Bhakti. 2004. Dalam Rofle, Jim (Ed.), The Asia-Pacific, A Region In Transition (hlm. 195-206). Honolulu: Asia Pacific Center For Security Studies

Kandiah, Michael D. 2012. Contemporary History (http://www.history.ac.uk/ makinghistory/ resources/article/contemporary_hist ory.html, Diunduh 3 Maret 2012).

Kingsbury, Damien. 2005. Power Politics And Indonesian Military. London: Taylor and Francis E-Library

Kuntowijoyo. 2001. Pengantar Ilmu Sejarah. Jogjakarta: Yayasan Bentang Budaya 2008. Penjelasan Sejarah. Yogyakarta: Tiara Wacana

Leo Batubara. 2009. Indonesia Bergelut Dalam Paradoks. Jakarta: Dewan Pers Indonesia

Louw, P. Eric. 2005. The Media And Political Process. London: Sage Publication Inc.

Mahkamah Konstitusi Republik Indonesia. 2006. Risalah Sidang Perkara No. 006/PUU/2006. Jakarta: Mahkamah Konstitusi Republik Indonesia

Miriam Budiardjo. 2011. Dasar Dasar Ilmu Politik. Jakarta: Gramedia Pustaka Utama

Pusat Bahasa Kemdiknas. 2008. Kamus Besar Bahasa Indonesia (online), (http://bahasa.kemdiknas.go.id/kbbi/ indeks.php, Diunduh 10 Mei 2012)

Roosa, John. 2006. Dalih Pembunuhan Massal, Gerakan 30 September Dan Kudeta Suharto. Terjemahan oleh Institut Sejarah Sosial Indonesia. 2008. Jakarta: ISSI dan Hasta Mitra

Student 2009, Microsoft (DVD). 2008. Newspaper. Redmon, WA: Microsoft Corporation

Suharto; G. Dwipayana; Ramadhan K.H. 1996. Soeharto, Pikiran, Ucapan Dan Tindakan Saya. Jakarta: Citra Lamtoro Gung Persada

Sukri Abdurrachman. 2003. Krisis Masa Kini Dan Orde Baru. Dalam Muhammad Hisyam (Ed.). Jakarta: Yayasan Obor Indonesia 
Sularto, St. 2011. Syukur Tiada Akhir, Jejak Langkah Jakob Oetama. Jakarta: Penerbit Buku Kompas.

Tim Iklan Kompas. 2012. About Kompas (online),

(http://www.kompasiklan.com/about , Diunduh 7 April 2012)

Tim Kompas Gramedia. 2012. Kompas (online), (http://www.kompasgramedia.com/ business/newspapers/kompas, Diunduh 12 Maret 2012)

Undang-Undang Republik Indonesia No 40 Tahun 1999 Tentang Pers (online), (http://komisiinformasi.go.id, Diunduh 1 Agustus 2012)

Vickers, Adrian. 2005. A History Of Modern

Indonesia. New York: Cambridge University

Press 